\title{
Design and Synthesis of Novel Indole $\beta$-Diketo Acid Derivatives as HIV-1 Integrase Inhibitors
}

\begin{abstract}
Mario Sechi, ${ }^{*}{ }^{\dagger}$ Massimiliano Derudas, ${ }^{\dagger}$ Roberto Dallocchio, ${ }^{\ddagger}$ Alessandro Dessì, ${ }^{\ddagger}$ Alessia Bacchi, ${ }^{\S}$ Luciano Sannia, ${ }^{\dagger}$ Fabrizio Carta, ${ }^{\dagger}$ Michele Palomba, ${ }^{\dagger}$ Omar Ragab," Carney Chan," Robert Shoemaker, ${ }^{\perp}$ Shizuko Sei, Raveendra Dayam," and Nouri Neamati*,ll Dipartimento Farmaco Chimi co Tossi col ogico, Università di Sassari, Via Muroni 23/ A, 07100 Sassari, Italy, CNR-I stituto di
Chimica Biomolecolare, sez. di Sassari, Trav. La Crucca 3, reg. Baldinca, 07040 Li Punti, Italy, Dipartimento di Chimica
Generale ed Inorganica, Chimica Analitica, Chimica Fisica, Università di Parma, Parco Area delle Scienze 17/ A,
43100 Parma, Italy, Department of Pharmaceutical Sciences, School of Pharmacy, University of Southern California,
1985 Zonal Avenue, PSC 304, Los Angeles, California 90089, and Screening Technol ogies Branch, DTP, DCTD, and
Laboratory of Antiviral Drug Mechanisms, SAIC-Frederick, National Cancer Institute at Frederick, Frederick, Maryland 21702
\end{abstract}

Received J anuary 19, 2004

Diketo acids such as S-1360 (1A) and L-731,988 (2) are potent and selective inhibitors of HIV-1 integrase (IN). A plethora of diketo acid-containing compounds have been claimed in patent literature without disclosing much biological activities and synthetic details (reviewed in Neamati, N. Exp. Opin. Ther. Pat. 2002, 12, 709-724). To establish a coherent structureactivity relationship among the substituted indole nucleus bearing a $\beta$-diketo acid moiety, a series of substituted indole- $\beta$-diketo acids $(\mathbf{4 a}-\mathbf{f}$ and $\mathbf{5 a}-\mathbf{e})$ were synthesized. All compounds tested showed anti-I N activity at low micromolar concentrations with varied sel ectivity against the strand transfer process. Three compounds, the indole-3- $\beta$-diketo acids $\mathbf{5 a}$ and $\mathbf{5 c}$, and the parent ester 9c, have shown an antiviral activity in cell-based assays. We further confirmed a keto-enolic structure in the 2,3-position of the diketo acid moiety of a representative compound (4c) using NMR and X-ray crystallographic analysis. Using this structure as a lead for all of our computational studies, we found that the title compounds extensively interact with the essential amino acids on the active site of I N.

\section{Introduction}

Despite significant advances in antiretroviral therapy, the search for new anti-HIV-1 agents continues in the attempt to devel op drugs capable of overcoming toxicity and resistance. ${ }^{1,2}$ Combination therapies for the treatment of HIV infection are mainly based on drugs targeting reverse transcriptase and protease. The rapid emergence of resistant variants, often cross-resistant to the members of a given class, limits the efficacy of existing antiretroviral drugs. ${ }^{3}$ In this context, new targets have been envisaged and suitable drugs are under development. 1,2 HIV-1 integrase (IN) is one of the targets whose inhibition might be very efficacious in preventing viral replication. In fact, integration of viral DNA into the host cell genome is a critical step in the HIV Iife cycle. This essential process is catalyzed by the viral enzyme IN through two different reactions: 3'processing and strand transfer.$^{4-6}$ I nitially, the enzyme recognizes the LTR termini of the viral dsDNA, of which it removes the last two nucleotides (GT), thus leaving two recessed 3'-OH ends (3'-processing reaction). Then, IN catalyzes the joining of the processed 3 '-ends to the 5 -ends of the host DNA (strand transfer reaction). ${ }^{7}$ The integration reaction is completed by the removal of

\footnotetext{
* To whom correspondence should be addressed. (M.S.) Tel: +39 079 228753. Fax: +39079 228720. E-mail: mario.sechi@uniss.it. (N.N.) Tel: 323-442-2341. Fax: 323-442-1390. E-mail: neamati@usc.edu. † Università di Sassari.

₹ CNR-Istituto di Chimica Biomolecolare

§ Università di Parma.

" University of Southern California.

$\perp$ Screening Technologies Branch, DTP, DCTD.

\# Laboratory of Antiviral Drug Mechanisms, SAIC-Frederick.
}

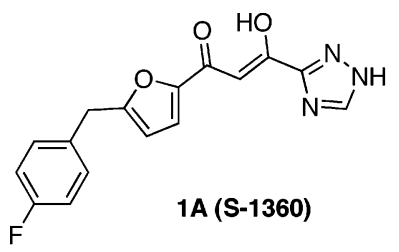<smiles>O=C(/C=C(\O)c1nn[nH]n1)c1c[nH]c2ccc(Cl)cc12</smiles><smiles>O=C(O)CC(=O)c1cccn1Cc1ccc(F)cc1</smiles><smiles>[R]c1ccc(Cc2ccccc2)cc1C(=O)CC(=O)O</smiles>

$\mathrm{R}=\mathrm{OCH}_{3}, \mathrm{OCH}_{2} \mathrm{CH}_{3}, \mathrm{OCH}\left(\mathrm{CH}_{3}\right)_{2}$

Figure 1. Structures of selected diketo acid-containing HIV-1 IN inhibitors.

unpaired nucleotides and gap repair by cellular enzymes that lead to provirus formation. Because no cellular homologue has been found in humans, IN is being considered as a promising target for the development of selective anti-AIDS drugs. ${ }^{8-10}$ Recently, a number of compounds bearing a diketo acid moi ety were independently discovered by scientists from Shionogi \& Co. and Merck (for recent reviews, see refs 9 and 11) as a new class of I N inhibitors. One of these compounds, 5CITEP (1B; F igure 1), was subsequently cocrystallized with the enzyme providing the first X-ray crystal structure of an inhibitor in complex with the HIV-1 IN.12 5CITEP belongs to the diketo acid-containing compounds, be cause the tetrazole group is a well-known bioisostere of a carboxylic acid. ${ }^{13}$ Selective strand transfer inhibitors $\mathbf{2}$ and $\mathbf{3}$ constitute major leads in anti-HIV-1 IN drug 


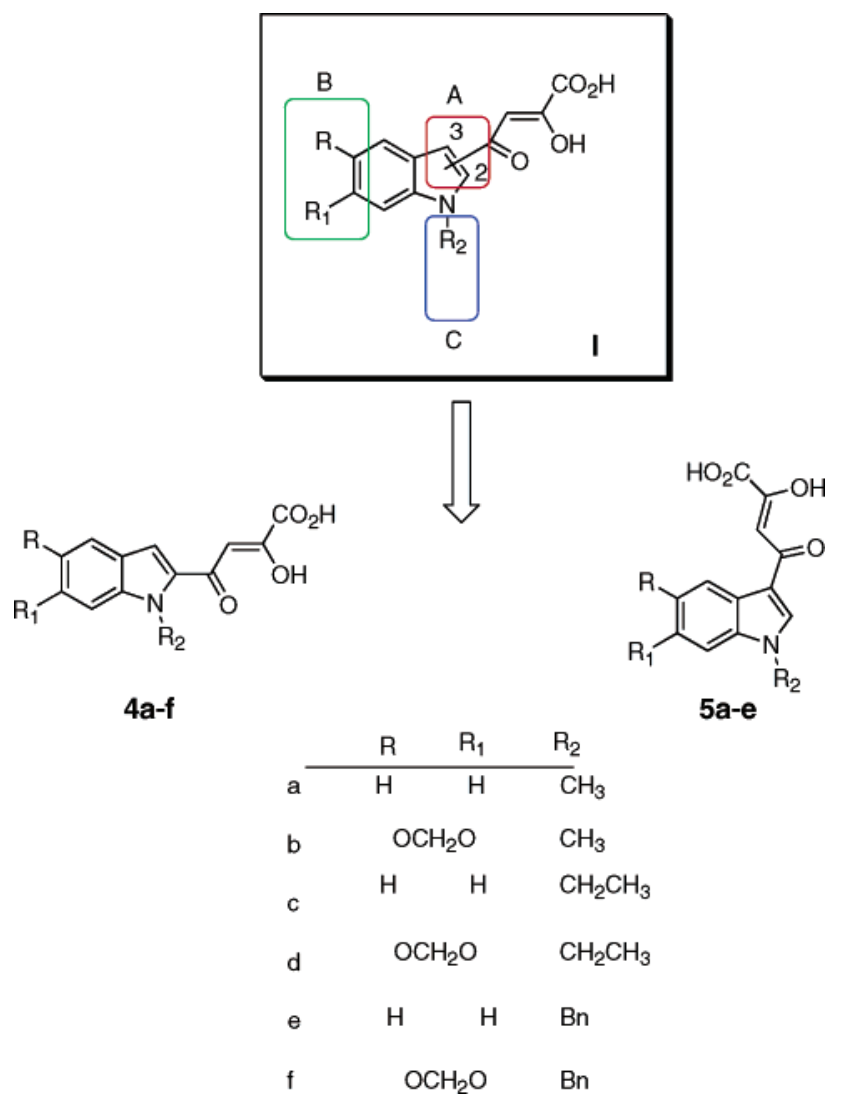

Figure 2. Design of target compounds $\mathbf{4 a}-\mathbf{f}$ and $\mathbf{5 a}-\mathbf{e}$.

discovery, and in cell-based assays, they inhibit integration without affecting earlier phases of the HIV-1 replication cycle. ${ }^{14-16}$

Although this class of compounds afforded promising leads for the development of IN inhibitors, only limited structure-activity relationships (SAR) and detailed synthetic studies of these inhibitors have been reported. $9,16,17$ In this context, on the basis of the assumption that the $\beta$-diketo acid moiety is necessary for the anti-I $\mathrm{N}$ activity, our aim was to examine several structural and biological features of these compounds. By combining important features of lead compounds $\mathbf{1 B}$ and $\mathbf{2}$, we designed a series of substituted indoles of general structure I (Figure 2). Therefore, we made three major modifications of I in order to better understand the role of different substituents on activity. First, positions 2 and 3 of the diketo moiety in the indole were initially explored to determine optimum geometry. Second, a dioxole ring was introduced to increase the extension of the molecular backbone. Third, $\mathrm{N}$-alkylation of the indole was introduced to modulate lipophilicity. These structural modifications led to compounds $\mathbf{4 a -}-\mathbf{f}$ and $\mathbf{5 a}-\mathbf{e}$ (Figure 2). Also, the inhibitory activity of the corresponding $\beta$-diketo ester intermediates $\mathbf{7 a}-\mathbf{d}, \mathbf{f}$ and $\mathbf{9 b}, \mathbf{c}$ was evaluated in order to establish a coherent SAR among these compounds.

To study the nature of the drug-binding sites, we extended our SAR studies to solve the crystal and solution structures of a representative compound. We also observed that selectivity against thestrand transfer process is important, but not essential, for antiviral activity.

\section{Results and Discussion}

Chemistry. Synthetic approaches for the preparation of target compounds $\mathbf{4 a}-\mathbf{f}$ and $\mathbf{5 a}-\mathbf{e}$ and their intermediates are depicted in Schemes 1-5. Indol 2-(3-)- $\beta$ diketo acids $4 \mathbf{a}-\mathbf{f}$ and $\mathbf{5 a}-\mathbf{e}$ were obtained by alkaline hydrolysis from their respective $\beta$-diketo ester $\mathbf{7 a}-\mathbf{f}$ and 9a-e intermediates. These intermediates were prepared by Claisen condensation ${ }^{18,19}$ of 2-acetylindoles $\mathbf{6 a}-\mathbf{f}$ and 3-acetylindoles $\mathbf{8 a}-\mathbf{e}$ with diethyl oxalate and sodium methoxide dissolved in $\mathrm{CH}_{3} \mathrm{OH}$ or THF (Scheme 1). Under these conditions, only methyl esters were obtained by a trans-esterification reaction between the methoxide and the ethyl esters. The parent compounds $\mathbf{6 a}-\mathbf{f}$ and $\mathbf{8} \mathbf{a}-\mathbf{e}$ were synthesized following different synthetic routes. Alkylation of esters $\mathbf{1 0}$ and $\mathbf{1 1}$ with appropriate alkyl halides in powdered $\mathrm{KOH} / \mathrm{DMSO}^{20}$ gave the corresponding alkyl indoles 12-15. Esters 17 and $\mathbf{1 8}$ were synthesized from commercially available compounds 16 under identical conditions. Acids 19a-f were in turn obtained in good yield upon alkaline hydrolysis. Their conversion into the desired acetyl derivatives $\mathbf{6 a - f}$ (Scheme 2) was performed using methyl lithium in diethyl ether ${ }^{21}$ The corresponding methyl ester $\mathbf{1 0}$ and the methyl di oxolindole-2-carboxylate $\mathbf{1 1}$ were prepared by cyclization of azidoesters $\mathbf{2 3}$ and $\mathbf{2 4}$ in refluxing xylene, according to the Hemetsberger reaction. ${ }^{22,23}$ The latter were easily obtained by Claisen condensation of aldehydes $\mathbf{2 0}$ and $\mathbf{2 1}$ with methyl azidoacetate $\mathbf{2 2}$ (Scheme 3). The 3-acetyl-indoles $\mathbf{8 a}, \mathbf{c}, \mathbf{e}$ were prepared by alkylation of available 3-acetylindole $\mathbf{2 5}$ with the appropriate alkyl halides (Scheme 4). The intermediates $\mathbf{8 b}, \mathbf{d}$ were instead obtained using the synthetic approach of Scheme 5. Thus, the esters $\mathbf{1 3}$ and $\mathbf{1 4}$ were first treated with trifluoroacetic anhydride, acetic acid, and $85 \%$ phosphoric acid to give the 3 -acetyl- derivatives $\mathbf{2 6}$ and $\mathbf{2 7}$ with $80 \%$ yiel ds. ${ }^{24}$ The latter compounds were converted into the acids $\mathbf{2 8}$ and $\mathbf{2 9}$ by alkaline hydrolysis with powdered $\mathrm{KOH}$ under refluxing ethanol. Finally, decarboxylation gave the expected 3-acetyl-dioxole-indoles 8b,d (Scheme 5).

Crystal and Solution Structures of Compound 4c. To determine whether the $\beta$-diketo acid moiety is present as $\beta$-diketo or its keto-enolic tautomer in solution and in solid state, a series of NMR and X-ray crystall ographic studies were carried out. The analysis of ${ }^{13} \mathrm{C} \mathrm{NMR}$ and distortionless enhancement by polarization transfer (DEPT) for compound $\mathbf{4 c}$ showed that the $\mathrm{CH}_{2}$ signal of the diketo moiety corresponded to $\mathrm{CH}$, an indication of the enolic form. Moreover, the ${ }^{13} \mathrm{C}$ NMR spectrum (chloroform-d) showed a signal at $101.9 \mathrm{ppm}$ (see Experimental Section) due to the $\mathrm{CH}$ enolic carbon whereas the resonance of the corresponding $\mathrm{CH}_{2}$ carbon of the diketo form was predicted to reside at about 5660 ppm upfield. 25,26 The DEPT experiment supports this observation, and only $\mathrm{C}-\mathrm{H}$ signals were observed in the aromatic region. The results of X-ray crystallographic data of compound $\mathbf{4 c}$ confirm that the enolic bond is situated in the 2,3-positions with respect to the carboxylic group of the $\beta$-diketo acid moiety (Figure 3, Tables 1 and 2, and Supporting Information). These observations are consistent with those of Bertolasi et al. who suggested that the enolic proton preferably resides on the carbon atom adjacent to the most electronegative group. ${ }^{27}$ The system is characterized by the 


\section{Scheme $1^{\text {a }}$}
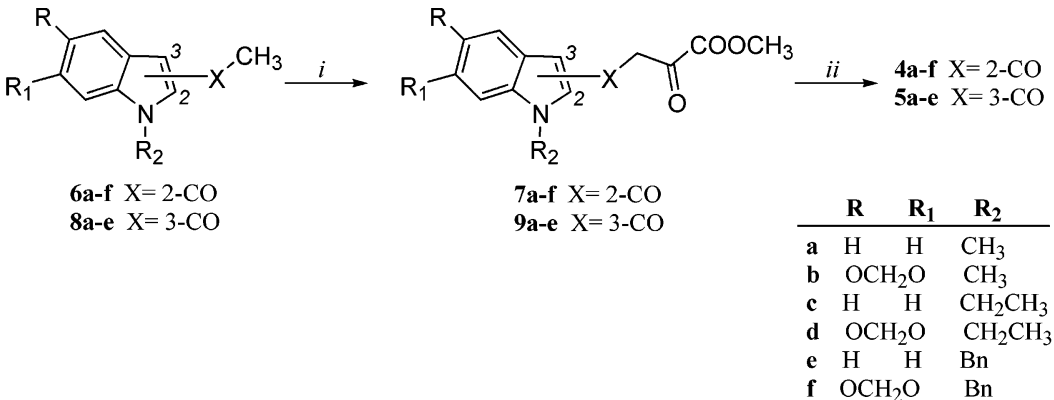

a Reagents and conditions: (i) Diethyloxalate, $\mathrm{CH}_{3} \mathrm{ONa}, \mathrm{CH}_{3} \mathrm{OH}$, reflux $4 \mathrm{~h}$ (THF, reflux $28 \mathrm{~h}$ for 9e). (ii) $2 \mathrm{~N} \mathrm{NaOH}, \mathrm{CH}_{3} \mathrm{OH}$, room temperature for $5 \mathrm{~h}, 1 \mathrm{~N} \mathrm{HCl}$.

\section{Scheme $2^{\mathrm{a}}$}

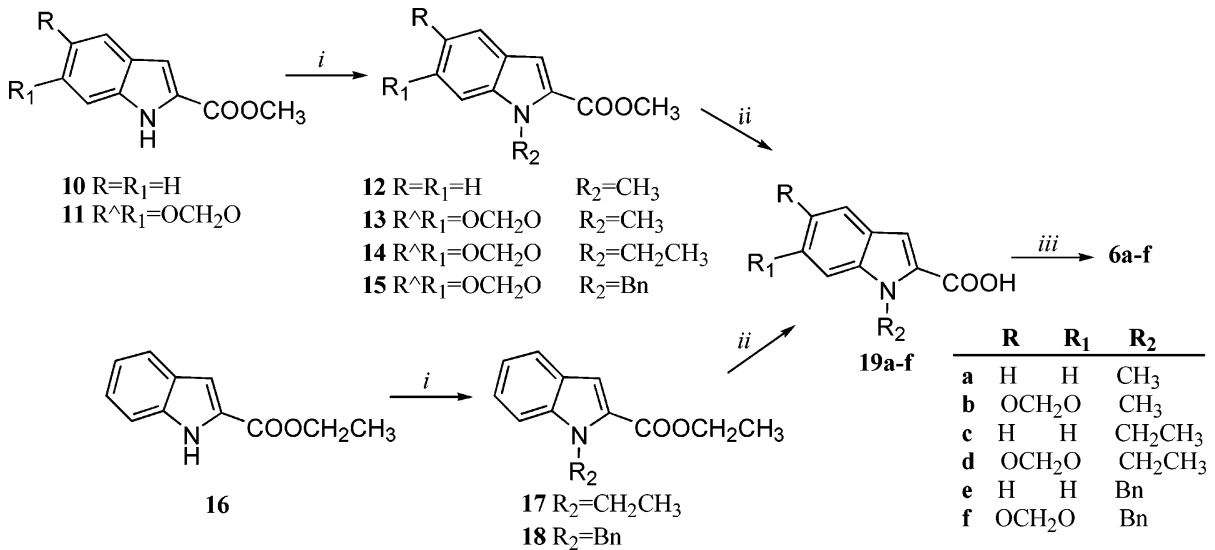

a Reagents and conditions: (i) $\mathrm{CH}_{3} \mathrm{l}, \mathrm{CH}_{3} \mathrm{CH}_{2} \mathrm{Br}$ or $\mathrm{BnBr}$, $\mathrm{KOH}$ pellets, DMSO, room temperature for $1 \mathrm{~h}$. (ii) $12 \% \mathrm{KOH}$, reflux for $1 \mathrm{~h}$, $1 \mathrm{~N} \mathrm{HCl}$. (iii) $1.4 \mathrm{M} \mathrm{CH}_{3} \mathrm{Li}$ in $\mathrm{Et}_{2} \mathrm{O}$, diethyl ether, reflux for $7 \mathrm{~h}$.

\section{Scheme $3^{a}$}

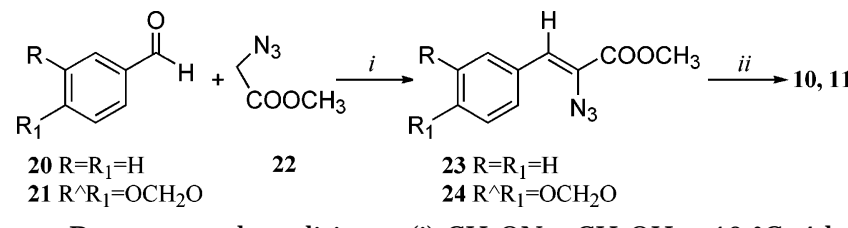

a Reagents and conditions: (i) $\mathrm{CH}_{3} \mathrm{ONa}, \mathrm{CH}_{3} \mathrm{OH},-10{ }^{\circ} \mathrm{C}, 4 \mathrm{~h}$. (ii) Xylene, reflux for $15 \mathrm{~min}$.

\section{Scheme $4^{a}$}

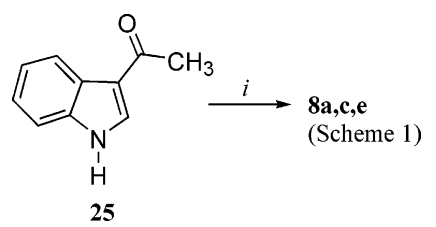

a Reagents and conditions: (i) $\mathrm{KOH}$ pellets, $\mathrm{CH}_{3} l, \mathrm{CH}_{3} \mathrm{CH}_{2} \mathrm{Br}$ or $\mathrm{BnBr}, \mathrm{DMSO}$, room temperature for $1 \mathrm{~h}$.

resonance-assisted intramolecular $\mathrm{H}$-bond (RAHB) between the enolic - $\mathrm{OH}$ donor group (O3) and the ketonic acceptor (04). The potential delocalization of double bond character on the keto-enolic skeleton gives particular strength to the interaction $[03 \cdots 04=2.610(2)$ $\AA$, O3-H $\cdots 04=147(3)^{\circ}$ ], as predicted by the RAHB paradigm. The same groups are also involved in an intermolecular $\mathrm{H}$-bond involving pairs of molecules related by a center of symmetry in the crystal packing. Thus, the $\mathrm{O3}-\mathrm{H}$ donor interacts with a $\mathrm{O} 4$ acceptor of a molecule located at the $(-x+2,-y,-z)$ position, forming a dimeric aggregate [H-bond geometry: $\mathrm{O3}-$ $\mathrm{H} \cdots 4^{\prime}(-\mathrm{x}+2,-\mathrm{y},-\mathrm{z}), 03 \cdots 4^{\prime}=2.943(2) \AA$, O3-
$\left.\mathrm{H} \cdot \cdot \mathrm{O}^{\prime}=113(2)^{\circ}\right]$. The most rel evant assembling mode of $\mathbf{4 c}$ in the solid state is however represented by the typical carboxylic acid dimeric association. This is based on very strong $\mathrm{H}$-bonds between $-\mathrm{COOH}$ groups that face each other in the crystal packing, belonging to pairs of molecules related by centers of inversion $(-x+1,-y$ $+1,-\mathrm{z})$. The $\mathrm{Cl}=\mathrm{O} 1[1.253(2) \AA]$ and $\mathrm{Cl}-\mathrm{O} 2-\mathrm{H}[1.254-$ (2) $\AA$ ] bonds in the carboxylate group are equivalent due to the remarkable strength of the $\mathrm{H}$-bond $[\mathrm{O} 2-\mathrm{H} \cdots \mathrm{O}]$ $(-x+1,-y+1,-z) \mathrm{O}-\mathrm{H}=1.31(5), \mathrm{O} \cdots \mathrm{O}=2.617(2)$, $\mathrm{H} \cdots \mathrm{O}=1.312(5), \mathrm{O}-\mathrm{H} \cdots \mathrm{O}=172(4)^{\circ}$ ], with the proton located exactly in the midpoint between the donor and the acceptor atoms (Table 2 and Supporting I nformation).

Biology. Compounds $\mathbf{4 a}-\mathbf{f}$ and $\mathbf{5 a}-\mathbf{e}$ inhibited purified IN at a low micromolar concentration range (Table 3). All compounds were more potent in inhibiting IN catalyzed strand transfer processes than the 3'-processing reactions, as previously reported for other derivatives of this class.9,15-17 In general, the diketo acid moiety constitutes a prominent structural feature for the selectivity for strand transfer and that the potency can be influenced by the aromatic portion. F or example, compounds $\mathbf{4 a}-\mathbf{f}$ and $\mathbf{5 a}-\mathbf{e}$ showed $5-50$-fold selectivity toward strand transfer in comparison to 3'-processing reaction (for a representative gel, see Figure 4). Interestingly, the dioxole ring as well as the position of the diketo acid function did not lead to a significant variation of anti-I $\mathrm{N}$ activity. Moreover, the presence of the alkyl substituents on the indolic nitrogen seems to not significantly influence the potency. Nevertheless, it is interesting to note that the best activity was displayed 


\section{Scheme $5^{a}$}

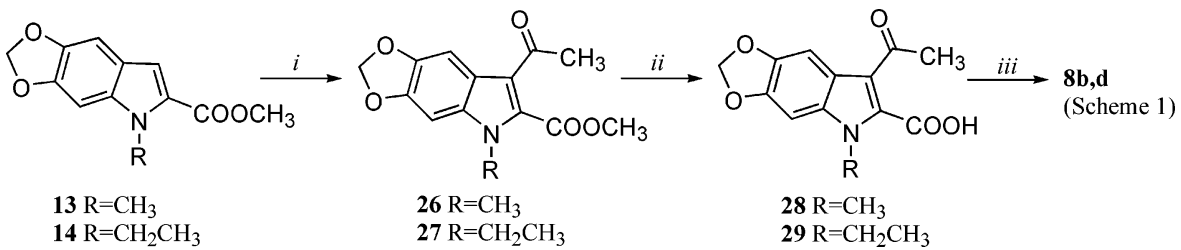

a Reagents and conditions: (i) $\left(\mathrm{CF}_{3} \mathrm{CO}\right)_{2} \mathrm{O}$, glacial $\mathrm{CH}_{3} \mathrm{COOH}, 85 \% \mathrm{H}_{3} \mathrm{PO}_{4}$, acetonitrile, room temperature for $14 \mathrm{~h}$. (ii) $\mathrm{KOH}$ pellets, $\mathrm{EtOH}$, reflux for $2-5 \mathrm{~h}, 6 \mathrm{~N} \mathrm{HCl}$. (iii) $\mathrm{CuCrO}_{2}$, quinoline, $200{ }^{\circ} \mathrm{C}, 50 \mathrm{~min}$.

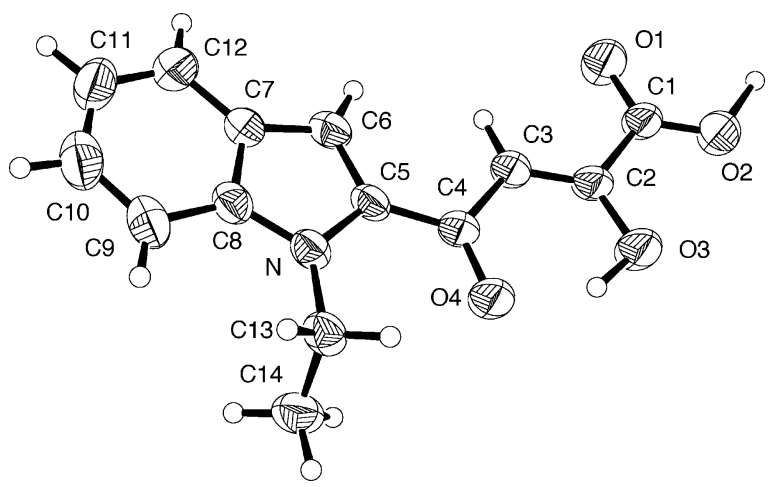

Figure 3. ORTEP diagram of $\mathbf{4 c}$ showing the atomic notation.

Table 1. Crystal Data and Structural Refinement for $\mathbf{4 c}$

\begin{tabular}{|c|c|}
\hline empirical formula & $\mathrm{C}_{14} \mathrm{H}_{13} \mathrm{NO}_{4}$ \\
\hline $\begin{array}{l}\text { formula weight } \\
\text { temperature }\end{array}$ & $\begin{array}{l}259.25 \\
293(2) \mathrm{K}\end{array}$ \\
\hline & $0.71069 \AA$ \\
\hline crystal system & monoclinic \\
\hline space group & $\mathrm{P} 2_{1} / \mathrm{n}$ \\
\hline unit cell dimensions $\left(\AA \AA{ }^{\circ}\right)$ & $\begin{array}{l}a=4.1535(6) \\
b=12.003(2)\end{array}$ \\
\hline & $C=24.963(4)$ \\
\hline & $\beta=90.543(3)$ \\
\hline volume & $1244.5(3) \AA^{3}$ \\
\hline & 4 \\
\hline calculated density & $1.384 \mathrm{Mg} / \mathrm{m}^{3}$ \\
\hline ption coefficient & $0.102 \mathrm{~mm}^{-1}$ \\
\hline$F(000)$ & 544 \\
\hline crystal size & $0.5 \times 0.4 \times 0.3 \mathrm{~mm}^{3}$ \\
\hline$\theta$ range for data collection & $1.63-23.27^{\circ}$ \\
\hline index ranges & $\begin{array}{r}-4 \leq h \leq 4,-12 \leq k \leq 13 \\
-27 \leq I \leq 27\end{array}$ \\
\hline reflections collected & 5360 \\
\hline independent reflections & $1793[\mathrm{R}$ (int) $=0.0340]$ \\
\hline mpleteness to $\theta=23.27^{\circ}$ & $99.8 \%$ \\
\hline absorption correction & symmetry-releted measurements \\
\hline max - min transmission factor & $1.00000-0.46069$ \\
\hline finement method & full-matrix least-squares on $\mathrm{F}^{2}$ \\
\hline ta/restraints/parameters & $1793 / 0 / 225$ \\
\hline odness-of-fit on $F^{2}$ & 1.017 \\
\hline final $\mathrm{R}$ indices $[I>2 \sigma(I)]$ & $\mathrm{R} 1=0.0398, \mathrm{wR} 2=0.1019$ \\
\hline indices (all data) & $\mathrm{R} 1=0.0568, \mathrm{wR} 2=0.1124$ \\
\hline nction coefficient & $0.005(2)$ \\
\hline rgest $\Delta \mathrm{F} \max / \min$ & $0.157 /-0.164$ e $\AA^{-3}$ \\
\hline
\end{tabular}

by the $\mathrm{N}$-benzyl derivatives $\mathbf{4 e}$ and $\mathbf{5 e}$. With identical ${ }^{\prime} C_{50}$ values $(1 \pm 0.5 \mu \mathrm{M})$, these compounds were the most potent inhibitors of the strand transfer reaction. This may be rationalized by correlating inhibitory potency with the size of the substituent on position 1 of the ring; the larger the substituent, the higher the activity is - no matter whether the diketo acid is present at position 2 or 3 of the indole. These results confirm that the $\beta$-diketo acid group reasonably influences the selectivity for one of the two catalytic steps and suggest that the indole nucleus all ows a consistent and sel ective inhibition to be maintained. Considerable variation in the inhibition of the 3 '-processing reaction $\left(\mathrm{IC}_{50}\right.$ values
Table 2. Bond Lengths $(\AA)$ and Angles $\left({ }^{\circ}\right)$ for $\mathbf{4 c}$

\begin{tabular}{|c|c|c|c|c|}
\hline bond & $\begin{array}{c}\text { length } \\
(\AA)\end{array}$ & $\begin{array}{l}\text { bond } \\
\text { type }\end{array}$ & bond & $\underset{\left({ }^{\circ}\right)}{\operatorname{ang}}$ \\
\hline $\mathrm{N}-\mathrm{C}(8)$ & $1.368(3)^{a}$ & & $\mathrm{O}(1)-\mathrm{C}(1)-\mathrm{C}(2)$ & 117.47(18) \\
\hline & & & $\mathrm{O}(2)-\mathrm{C}(1$ & \\
\hline$-C(13)$ & $1.465(2)$ & & $\mathrm{O}(3)-\mathrm{C}(2)-\mathrm{C}$ & \\
\hline (1) $-C(1)$ & $1.253(2)$ & 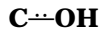 & $\mathrm{O}(3)-\mathrm{C}(2)-\mathrm{C}(1)$ & 112.94 \\
\hline (2) $-C(1)$ & & & $C(3)-C(2)-c$ & \\
\hline (2) & & $\mathrm{C}-\mathrm{OH}$ & $-C(3)-c$ & (19) \\
\hline (4) $-C$ (4) & & & $\mathrm{O}(4)-\mathrm{C}(4)-\mathrm{C}$ & \\
\hline & & & & \\
\hline (3) & & $\mathbf{C}=\mathbf{C}$ & $-C(4)-C(3)$ & \\
\hline & & & $-C(5)-N$ & \\
\hline$-C(5)$ & & & & \\
\hline$C(5)-C(6)$ & 1.37 & & $N-C(5)-C(4)$ & (17) \\
\hline & & & $-C(7)$ & \\
\hline (7) $-C(12)$ & & & 2) $-C(7)-C(6)$ & \\
\hline$C(7)-C(8)$ & 1.410 & & $C(12)-C(7)-C(8)$ & $119.7(2)$ \\
\hline (8) $-C(9)$ & & & $C(6)-C(7)-C(8)$ & $106.06(18$ \\
\hline (9) $-\mathrm{C}(10)$ & & & $\mathrm{N}-\mathrm{C}(8)-$ & \\
\hline (10)-C(11) & & & $N-C(8)-($ & 109.16(17) \\
\hline$C(11)-C(12)$ & & & $-C(8)-C(7)$ & $121.2(2)$ \\
\hline$=(13)-C(14)$ & 1.502 & & $C(10)-C(9)-C(8))$ & $116.9(2)$ \\
\hline (8) $-N-C(5)$ & 107.72( & & $C(9)-C(10)-C(11)$ & $122.9(2)$ \\
\hline $\mathrm{C}(8)-\mathrm{N}-\mathrm{C}(13)$ & & & $C(12)-C(11)-C(10)$ & \\
\hline $\mathrm{C}(5)-\mathrm{N}-\mathrm{C}(13)$ & $128.47(16)$ & & $\mathrm{C}(11)-\mathrm{C}(12)-\mathrm{C}(7)$ & $118.7(3)$ \\
\hline$U(1)-C(1)-U(2)$ & $124.66(19)$ & & $\mathrm{N}-\mathrm{C}(13)-\mathrm{C}(14)$ & 113.12(18) \\
\hline
\end{tabular}

a In parentheses are the su values. Parameters relevant to the discussion are shown in boldface.

Table 3. Inhibition of HIV-1 IN Catalytic Activities and Antiviral Activities of Indole $\beta$-diketo Derivatives

\begin{tabular}{ccccccc}
\hline \multicolumn{7}{c}{$3^{\prime}$-processing strand transfer } \\
compd & $\mathrm{IC}_{50}(u \mathrm{M})$ & $\mathrm{IC}_{50}(\mu \mathrm{M})$ & $\mathrm{SI}^{\mathrm{a}}$ & $\mathrm{CC}_{50}{ }^{\mathrm{b}}$ & $\mathrm{EC}_{50}{ }^{\mathrm{c}}$ & $\mathrm{TI}^{\mathrm{d}}$ \\
\hline $\mathbf{4 a}$ & $50 \pm 15$ & $6 \pm 2$ & 8 & 81 & $>81$ & \\
$\mathbf{4 b}$ & $11 \pm 4$ & $2 \pm 1$ & 5 & $>200$ & $>200$ & \\
$\mathbf{4 c}$ & $16 \pm 5$ & $1.6 \pm 1$ & 10 & 110 & $>110$ & \\
$\mathbf{4 d}$ & $55 \pm 6$ & $5 \pm 1$ & 11 & 57 & $>57$ & \\
$\mathbf{4 e}$ & $20 \pm 3$ & $1 \pm 0.5$ & 20 & $\mathrm{ND}$ & $\mathrm{ND}$ & \\
$\mathbf{4 f}$ & $35 \pm 5$ & $2 \pm 1$ & 17 & 3.8 & $>3.8$ & \\
$\mathbf{5 a}$ & $100 \pm 10$ & $2 \pm 1$ & 50 & $>200$ & $37 \pm 5$ & $>5.4$ \\
$\mathbf{5 b}$ & $100 \pm 10$ & $3 \pm 2$ & 33 & 108 & $>108$ & \\
$\mathbf{5 c}$ & $93 \pm 23$ & $3 \pm 1$ & 31 & $108 \pm 24$ & $9 \pm 1$ & 12 \\
$\mathbf{5 d}$ & $45 \pm 5$ & $3 \pm 2$ & 15 & $>200$ & $123 \pm 9$ & $>1.6$ \\
$\mathbf{5 e}$ & $12 \pm 8$ & $1 \pm 0.5$ & 12 & $\mathrm{ND}$ & $\mathrm{ND}$ & \\
$\mathbf{7 a}$ & $100 \pm 10$ & $45 \pm 10$ & 2 & 106 & $>106$ & \\
$\mathbf{7 b}$ & $100 \pm 10$ & $50 \pm 20$ & 2 & $>200$ & $>200$ & \\
$\mathbf{7 c}$ & $\mathrm{ND}$ & $\mathrm{ND}$ & $\mathrm{ND}$ & 60 & $>60$ & \\
$\mathbf{7 d}$ & $85 \pm 20$ & $65 \pm 7$ & 1.3 & 75 & $>75$ & \\
$\mathbf{7 f}$ & $100 \pm 20$ & $14 \pm 8$ & 7 & 1.1 & $>1.1$ & \\
$\mathbf{9 b}$ & $>100$ & $60 \pm 30$ & $>1.6$ & 31 & $>31$ & \\
$\mathbf{9 c}$ & $>100$ & $26 \pm 5$ & $>3.8>200$ & $19 \pm 4$ & $>10.5$ \\
\hline
\end{tabular}

a $\mathrm{SI}$, selectivity index. ${ }^{\mathrm{b}} \mathrm{CC}_{50}$, cytotoxic concentration $50 \%$. ${ }^{\mathrm{C}} \mathrm{EC}_{50}$, effective concentration $50 \%$. ${ }^{\mathrm{d}} \mathrm{TI}$, therapeutic index $=\mathrm{CC}_{50}$ $\mathrm{EC}_{50}$; ND, not determined.

range from 11 to $100 \mu \mathrm{M}$ ) played a significant role in the selectivity index $(\mathrm{SI})$ results. This implies that most of these compounds are loosely bound to the preassembled IN-DNA complex, whereas they are tightly bound to postassembled IN-DNA complexes.

Another interesting feature that could potentially play a major role in the inhibition of IN is the ability to chelate a divalent metal ion on the active site of I $\mathrm{N}$ and 
A

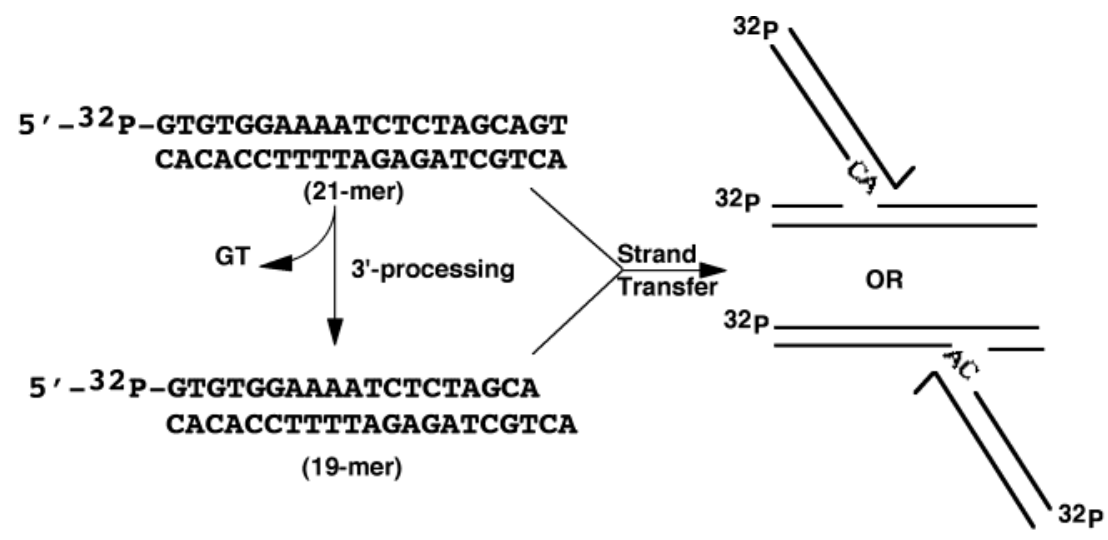

B

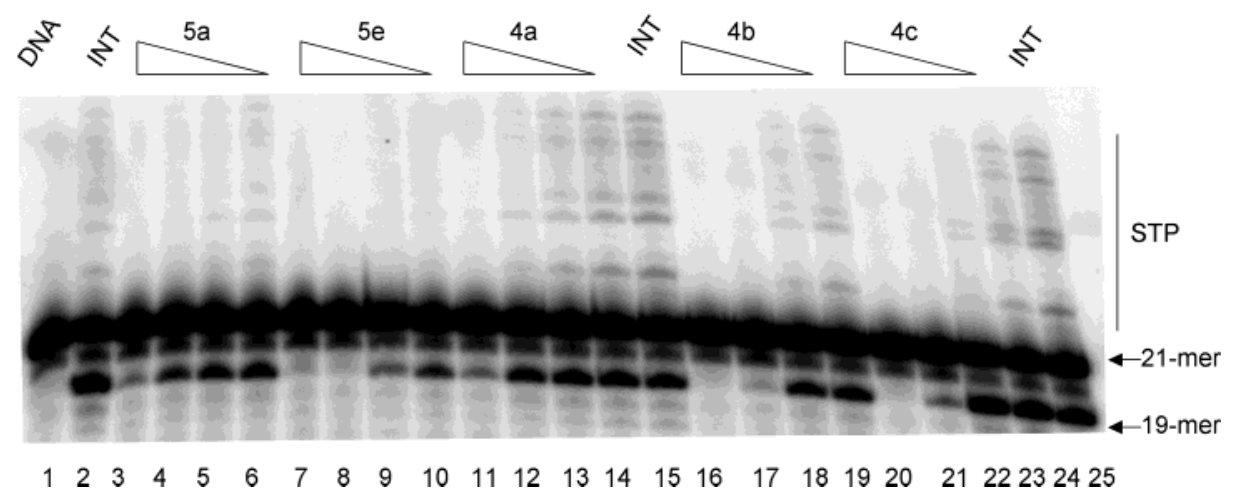

Figure 4. Representative gel showing inhibition of purified IN by selected compounds. (A) A 21-mer blunt end oligonucleotide corresponding to the U5 end of the HIV-1 LTR, 5'-end-labeled with ${ }^{32} \mathrm{P}$, is reacted with purified IN. The initial step involves nucleolytic cleavage of two bases from the 3'-end, resulting in a 19-mer oligonucleotide. Subsequently, 3'-ends are covalently joined at several sites to another identical oligonucleotide that serves as the target DNA. This reaction is referred to as strand transfer, and the products formed migrate slower than the original substrate (shown in the figure as STP for strand transfer products). (B) Lane 1, DNA alone; Ianes 2, 15, and 25, IN and DNA with no drug; and lanes 3-24, IN, DNA, and selected drug concentrations (100,33.3, 11.1, and $3.7 \mu \mathrm{M}$ ) indicated above each lane.

possibly interfere with the target DNA. Although all crystal structures of I $\mathrm{N}$ reveal a single binding site for $\mathrm{Mg}^{2+}$, several studies suggest a plausible model in which the IN active site binds two metal ions. ${ }^{28-30}$ This phenomenon could perhaps explain the variability in potency between the inhibitors. For example, we ob-

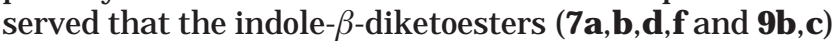
exhibit much reduced inhibitory potencies than their respective acids and only compound $7 f$ showed an interesting selectivity toward the strand transfer process $(\mathrm{SI}=7)$. These results could be explained considering the ability of both carboxylic and diketo functionalities to potentially chelate two divalent ions where the diketo esters bind preferably to only one. This clearly indicates that the free carboxylic function is necessary for a strong interaction with the catalytic residues on the I $\mathrm{N}$ active site, particularly a metal ion.

As far as the antiviral activity is concerned, only indole-3- $\beta$-derivatives inhibited the HIV-1 cytopathic effect in cell-based assays at non cytotoxic concentrations. $\mathrm{EC}_{50}$ values were $37 \pm 5,9 \pm 1$, and $19 \pm 4 \mu \mathrm{M}$ for $\mathbf{5 a}, \mathbf{5 c}$, and $\mathbf{9 c}$, respectively. From the data presented in Table 3, an additional observation could be made concerning the correlation of the compound's cytotoxicity with their molecular size. For example, the acid $\mathbf{4 f}$ and its respective ester 7f, which contain a bulky benzyl group and a dioxole ring, were the most cytotoxic $\left(\mathrm{CC}_{50}\right.$ $=3.8$ and $1.1 \mu \mathrm{M}$ ) of the tested compounds. Unfortunately, compounds $\mathbf{4 a}-\mathbf{f}$ and $\mathbf{5 b} \mathbf{b}, \mathbf{d}$, although endowed with selective activity against IN (Figure 4), proved to be ineffective in preventing the HIV-1 cytopathic effect in cell-based assays. A possible explanation for these results could come from SAR studies by Wai et al. ${ }^{16}$ on compounds exemplified by $\mathbf{3}$. The authors highlighted the importance of rel ative orientations between the aryl substituents and the diketo acid moiety and have also stated that the intrinsic potency against IN and the antiviral activity increases as the angle of bisection increases from 60 to $118^{\circ}$. This conclusion supports our suggestion that the indole moiety fulfills the require ments for 1,3-aryl disubstitution for the most active compounds $\mathbf{5 a}, \mathbf{c}$ and $\mathbf{9 c}$. The antiviral potency of $\mathbf{9 c}$ could be attributed to the favorable structural combination of the aromatic framework and its $\beta$-diketo ester moiety. However, we cannot rule out the possibility that 9c could potentially hydrolyze to a free acid upon cellular uptake.

Docking Studies. Several computational docking studies using the crystal structures of the IN core domain and known inhibitors have recently been reported. ${ }^{31-38}$ In most studies, the bound conformation of 5 CITEP in the IN-5CITEP cocrystal structure could not be reproduced perhaps due to the crystal packing effects. To identify the bioactive conformations of indole $\beta$-diketo acid derivatives $\mathbf{4 a - 9 c}$, we docked all of the title compounds onto the IN active site using GOLD. The core domain of IN (PDB 1BIS), wherein all of the amino acid residues in the active site region were resolved, was consi dered for docking purposes. The best bound conformations (the bound conformation with the 
highest fitness score) of some of the compounds are shown in Figure 5. The observed $\mathrm{H}$-bonding and metalcompound interactions are given in Tables 4 and 5. A trend was observed between 3'-processing activity and GOLD fitness scores, where potent compounds scored favorable binding energies while some of the inactive compounds scored low. The predicted bound conformation of the compounds was highly sensitive to the substituents on the indole core unit. The presence of the $\mathrm{H}$-bond donor or acceptor and steric (hydrophobic) groups significantly influenced the binding preferences of the compounds.

Compounds with free acid adopted different bound conformations than the esters (Figure 5). The carboxylate functionality of $\beta$-diketo acids formed strong $\mathrm{H}$ bonding interactions with N155 and K159 (Table 4). The dioxole-bearing compounds adopted similar bound conformations, and the dioxole group formed strong $\mathrm{H}$ bonding interactions with N 155 and K 159. Compounds with a benzyl substituent on indolic nitrogen adopted a very different bound conformation than compounds with methyl or ethyl substituents. Recurring and strong interactions were observed between several compounds and active site amino acid residues, such as K 159, N 155, E 152, I 151, D116, E 92, C65, H67, D64, and Q62. Some of these amino acids are very important for the catalytic activity of IN. ${ }^{39}$ The predicted bound conformations, and especially their predominant interactions with active site amino acid residues K159, N 155, D64, and $\mathrm{Mg}^{2+}$, may explain the inhibitory profiles of the title compounds.

Conclusion. We have demonstrated that the diketo acid functionality is important for selectivity against strand transfer and that the aromatic ring plays a major role in potency. Our results clearly demonstrate that selectivity for strand transfer is not sufficient for antiviral activity. Moreover, the high throughput assays designed to selectively identify inhibitors of the strand transfer step of the catalysis fail to discover potential inhibitors of the 3'-processing step. Although diketo acid-containing compounds represent a novel class of compounds and are considered as a step forward in drug design in targeting IN, many analogues showed significant cytotoxicity and lack of antiviral activity. A prerequisite for all strand transfer inhibitors must be an efficient nuclear uptake. It is, therefore, important to bear in mind that the physicochemical properties of a compound could potentially make a major contribution to antiviral activity in vivo (for a recent review, see ref 40).

\section{Experimental Section}

Chemistry. Anhydrous solvents and all reagents were purchased from Aldrich, Merck, or Carlo Erba. Anhydrous diethyl ether was obtained by distillation from $\mathrm{Na}$ /benzophenone under nitrogen. All reactions involving air or moisture sensitive compounds were performed under a nitrogen atmosphere using oven-dried glassware and syringes to transfer solutions. Melting points ( $\mathrm{mp}$ ) were determined using an Electrothermal or a Köfler apparatus and are uncorrected. I nfrared (IR) spectra were recorded as thin films or Nujol mulls on $\mathrm{NaCl}$ plates with a Perkin-EImer 781 I R spectrophotometer and are expressed in $v\left(\mathrm{~cm}^{-1}\right)$. Nuclear magnetic resonance ( ${ }^{1} \mathrm{H} N M R,{ }^{13} \mathrm{C} N M R$, and DEPT) spectra were determined in $\mathrm{CDCl}_{3}, \mathrm{DMSO} \mathrm{d}_{6}$, or $\mathrm{CDCl}_{3} / \mathrm{DMSO}-\mathrm{d}_{6}$ (1:3 ratio) on a Varian XL-200 (200 MHz) as described. ${ }^{41,42}$ Chemical shifts ( $\delta$ scale) are reported in parts per million (ppm) downfield from tetramethylsilane (TMS) used as an internal standard. Splitting patterns are designated as follow: $s=$ singlet, $d=$ doublet, $\mathrm{t}=$ triplet, $\mathrm{q}=$ quadruplet, $\mathrm{m}=$ multiplet, $\mathrm{bs}=$ broad singlet, and $\mathrm{dd}=$ double doublet. The assignment of exchangeable protons $(\mathrm{OH}$ and $\mathrm{NH})$ was confirmed by the addition of $\mathrm{D}_{2} \mathrm{O}$. Electron ionization mass spectra (70 eV) were recorded on a Hewlett-Packard 5989 Mass Engine Spectrometer. Analytical thin-layer chromatography (TLC) was done on Merck silica gel F-254 plates. Pure compounds showed a single spot on TLC. For flash chromatography, Merck Silica gel 60 was used with a particle size $0.040-0.063 \mathrm{~mm}$ (230-400 mesh ASTM). Elemental analyses were performed on a Perkin-EImer 2400 instrument at Laboratorio di Microanalisi, Dipartimento di Chimica, Università di Sassari, Italy, and the results were within $\pm 0.4 \%$ of the theoretical values.

General Procedure for the Preparation of Indole $\boldsymbol{\beta}$-diketo Acids (4a-f and $\mathbf{5 a}-\mathbf{e})$. A solution of an appropriate indole $\beta$-diketo ester $(\mathbf{7 a}-\mathbf{f}$ and $\mathbf{9 a}-\mathbf{e})(1 \mathrm{mmol})$ and $2 \mathrm{~N} \mathrm{NaOH}$ (4 equiv) in methanol ( $15 \mathrm{~mL}$ ) was stirred at room temperature for $5 \mathrm{~h}$. After dilution with water, the mixture was acidified with $1 \mathrm{~N} \mathrm{HCl}$. The yellow or orange precipitate that formed was filtered off, washed with water, and recrystallized from water/ethanol.

2-Hydroxy-4-(1-methyl-1H-indol-2-yl)-4-oxobut-2-enoic Acid (4a). Y ield: $62 \% ; \mathrm{mp} 186-188^{\circ} \mathrm{C}$. IR (Nujol): $\mathrm{v} \mathrm{cm}^{-1}$ $1610(\mathrm{C}=\mathrm{O}), 1710\left(\mathrm{C}=\mathrm{O}\right.$ acid). ${ }^{1} \mathrm{H}$ NMR $\left(\mathrm{CDCl}_{3}\right): \delta 7.69(1 \mathrm{H}$, $\mathrm{d}, \mathrm{Ar}-\mathrm{H}), 7.47-7.43(3 \mathrm{H}, \mathrm{m}, \mathrm{Ar}-\mathrm{H}), 7.20-7.12(1 \mathrm{H}, \mathrm{m}, \mathrm{Ar}-$ $\mathrm{H}), 7.07(1 \mathrm{H}, \mathrm{s}, \mathrm{HC}=\mathrm{C}), 5.10-3.90(1 \mathrm{H}, \mathrm{bs}, \mathrm{COOH}), 4.12(3 \mathrm{H}$, S, $\left.\mathrm{CH}_{3}\right)$. MS: m/z $245\left(\mathrm{M}^{+}, 4\right), 172$ (base). Anal. $\left(\mathrm{C}_{13} \mathrm{H}_{11} \mathrm{NO}_{4}\right)$ $\mathrm{C}, \mathrm{H}, \mathrm{N}$.

2-Hydroxy-4-(5-methyl-5H-[1,3]dioxolo[4,5-f]indol-6yl)-4-oxobut-2-enoic Acid (4b). Y ield: $55 \%$; $\mathrm{mp} 227-228^{\circ} \mathrm{C}$. IR (Nujol): $v \mathrm{~cm}^{-1} 1660$ ( $\left.\mathrm{C}=\mathrm{O}\right), 1700$ ( $\mathrm{C}=\mathrm{O}$ acid). ${ }^{1} \mathrm{H}$ NMR $\left(\mathrm{CDCl}_{3}+\right.$ DMSO- $\left.\mathrm{d}_{6}\right): \delta 7.35(1 \mathrm{H}, \mathrm{s}, \mathrm{Ar}-\mathrm{H}), 7.00(1 \mathrm{H}, \mathrm{s}$, $\mathrm{HC}=\mathrm{C}), 6.97(1 \mathrm{H}, \mathrm{s}, \mathrm{Ar}-\mathrm{H}), 6.91(1 \mathrm{H}, \mathrm{s}, \mathrm{Ar}-\mathrm{H}), 6.03(2 \mathrm{H}, \mathrm{s}$, $\left.\mathrm{OCH}_{2} \mathrm{O}\right), 4.06\left(3 \mathrm{H}, \mathrm{s}, \mathrm{CH}_{3}\right), 4.60-3.00(1 \mathrm{H}, \mathrm{bs}, \mathrm{COOH}) . \mathrm{MS}$ : $\mathrm{m} / \mathrm{z} 289\left(\mathrm{M}^{+}, 3\right), 216$ (base). Anal. $\left(\mathrm{C}_{14} \mathrm{H}_{11} \mathrm{NO}_{6} \cdot 0.15 \mathrm{H}_{2} \mathrm{O}\right) \mathrm{C}, \mathrm{H}$, N.

4-(1-E thyl-1H-indol-2-yl)-2-hydroxy-4-oxobut-2-enoic Acid (4c). Yield: $72 \% ; \mathrm{mp} 170-172{ }^{\circ} \mathrm{C}$. IR (Nujol): $\mathrm{v} \mathrm{cm}^{-1} 1630$ $(\mathrm{C}=\mathrm{O}), 1690(\mathrm{C}=\mathrm{O}$ acid $) .{ }^{1} \mathrm{H} N M R\left(\mathrm{CDCl}_{3}\right): \delta 7.71(1 \mathrm{H}, \mathrm{d}, \mathrm{Ar}-$ $\mathrm{H}), 7.49(1 \mathrm{H}, \mathrm{s}, \mathrm{Ar}-\mathrm{H}), 7.45-7.32(2 \mathrm{H}, \mathrm{m}, \mathrm{Ar}-\mathrm{H}), 7.18(1 \mathrm{H}$, $\mathrm{d}, \mathrm{Ar}-\mathrm{H}), 7.14(\mathrm{H}, \mathrm{s}, \mathrm{CH}=\mathrm{C}), 4.67\left(2 \mathrm{H}, \mathrm{q}, \mathrm{J} 6.4 \mathrm{~Hz}, \mathrm{CH}_{2}\right)$, 3.80-3.10 (1H, bs, $\left.\mathrm{COOH}), 1.42(3 \mathrm{H}, \mathrm{t}\rfloor ,6.4 \mathrm{~Hz}, \mathrm{CH}_{3}\right) .{ }^{13} \mathrm{C}$ NMR $\left(\mathrm{CDCl}_{3}\right): \delta 187.1(\mathrm{CO}), 164.1(\mathrm{C}=\mathrm{COH}), 162.2(\mathrm{COOH})$, $140.0\left(\mathrm{C}_{2}\right), 133.4\left(\mathrm{C}_{7 \mathrm{a}}\right), 126.5\left(\mathrm{C}_{5}\right), 126.1\left(\mathrm{C}_{4 \mathrm{a}}\right), 123.1\left(\mathrm{C}_{4}\right), 120.9$ $\left(\mathrm{C}_{6}\right), 112.7\left(\mathrm{C}_{3}\right), 110.3\left(\mathrm{C}_{7}\right), 101.9(\mathrm{C}-\mathrm{H}), 40.2\left(\mathrm{CH}_{2}\right), 15.4\left(\mathrm{CH}_{2}\right)$. MS: m/z $259\left(\mathrm{M}^{+}, 8\right), 171$ (base). Anal. $\left(\mathrm{C}_{14} \mathrm{H}_{13} \mathrm{NO}_{4}\right) \mathrm{C}, \mathrm{H}, \mathrm{N}$.

4-(5-Ethyl-5H-[1,3]dioxolo[4,5-f]indol-6-yl)-2-hydroxy4-oxobut-2-enoic Acid (4d). Y ield: 38\%; mp 210-211 ${ }^{\circ} \mathrm{C}$. IR (Nujol): $\mathrm{v} \mathrm{cm}^{-1} 1620(\mathrm{C}=\mathrm{O}), 1700\left(\mathrm{C}=\mathrm{O}\right.$ acid). ${ }^{1} \mathrm{H} \mathrm{NMR}\left(\mathrm{CDCl}_{3}\right.$ + DMSO-d 6 ): $\delta 7.46(1 \mathrm{H}, \mathrm{s}, \mathrm{Ar}-\mathrm{H}), 7.15-7.04(2 \mathrm{H}, \mathrm{m}, \mathrm{Ar}-\mathrm{H}$ $+\mathrm{CH}=\mathrm{C}), 6.96(1 \mathrm{H}, \mathrm{s}, \mathrm{ArH}) 6.04\left(2 \mathrm{H}, \mathrm{s}, \mathrm{OCH}_{2} \mathrm{O}\right), 5.20-4.30$ $(1 \mathrm{H}, \mathrm{bs}, \mathrm{COOH}), 4.57\left(2 \mathrm{H}, \mathrm{q}\right.$, J $\left.6.6 \mathrm{~Hz}, \mathrm{CH}_{2}\right), 1.31(3 \mathrm{H}, \mathrm{t}, \mathrm{J} 6.6$ $\left.\mathrm{Hz}, \mathrm{CH}_{3}\right) . \mathrm{MS}: \mathrm{m} / \mathrm{z} 303\left(\mathrm{M}^{+}, 5\right), 188$ (base). Anal. $\left(\mathrm{C}_{15} \mathrm{H}_{13} \mathrm{NO}_{6}\right)$ $\mathrm{C}, \mathrm{H}, \mathrm{N}$.

4-(1-Benzyl-1H-indol-2-yl)-2-hydroxy-4-oxobut-2-enoic Acid (4e). Yield: $68 \%$; $\mathrm{mp} 158-160{ }^{\circ} \mathrm{C}$. IR (Nujol): $\mathrm{v} \mathrm{cm}^{-1}$ $1610(\mathrm{C}=\mathrm{O}), 1730$ ( $\mathrm{C}=\mathrm{O}$ acido). ${ }^{1} \mathrm{H} \mathrm{NMR}\left(\mathrm{CDCl}_{3}\right): \delta 7.74(\mathrm{H}$, d, $\mathrm{Ar}-\mathrm{H}), 7.51(\mathrm{H}, \mathrm{s}, \mathrm{Ar}-\mathrm{H}), 7.39-7.33(3 \mathrm{H}, \mathrm{m}, \mathrm{Ar}-\mathrm{H}), 7.24-$ $7.18(5 \mathrm{H}, \mathrm{m}, \mathrm{Ar}-\mathrm{H}), 7.11(1 \mathrm{H}, \mathrm{s}, \mathrm{CH}=\mathrm{C}), 5.90\left(2 \mathrm{H}, \mathrm{s}, \mathrm{CH}_{2}\right)$, 5.40-3.80 (1H, bs, $\mathrm{COOH})$. MS: $\mathrm{m} / \mathrm{z} 321\left(\mathrm{M}^{+}, 8\right), 90$ (base). Anal. $\left(\mathrm{C}_{19} \mathrm{H}_{15} \mathrm{NO}_{4}\right) \mathrm{C}, \mathrm{H}, \mathrm{N}$.

4-(5-Benzyl-5H-[1,3]dioxolo[4,5-f]indol-6-yl)-2-hydroxy4-oxobut-2-enoic Acid (4f). Y ield: $39 \%$; $\mathrm{mp} 178-182^{\circ} \mathrm{C}$. IR (Nujol): $\mathrm{v} \mathrm{cm}^{-1} 1620(\mathrm{C}=\mathrm{O}), 1710\left(\mathrm{C}=\mathrm{O}\right.$ acid). ${ }^{1} \mathrm{H} \mathrm{NMR}\left(\mathrm{CDCl}_{3}\right.$ + DMSO- $\left._{6}\right): \delta 7.44(1 \mathrm{H}, \mathrm{s}, \mathrm{Ar}-\mathrm{H}), 7.25-7.21(5 \mathrm{H}, \mathrm{m}, \mathrm{Ar}-$ $\mathrm{H}), 7.04-6.98(2 \mathrm{H}, \mathrm{m}, \mathrm{Ar}-\mathrm{H}+\mathrm{CH}=\mathrm{C}), 6.80(1 \mathrm{H}, \mathrm{s}, \mathrm{Ar}-\mathrm{H})$, $5.98\left(2 \mathrm{H}, \mathrm{s}, \mathrm{OCH}_{2} \mathrm{O}\right), 5.83\left(2 \mathrm{H}, \mathrm{s}, \mathrm{CH}_{2}\right) . \mathrm{MS}: \mathrm{m} / \mathrm{z} 365\left(\mathrm{M}^{+}, 6\right)$, 90 (base). Anal. $\left(\mathrm{C}_{20} \mathrm{H}_{15} \mathrm{NO}_{6} \cdot 0.27 \mathrm{H}_{2} \mathrm{O}\right) \mathrm{C}, \mathrm{H}, \mathrm{N}$

2-Hydroxy-4-(1-methyl-1H-indol-3-yl)-4-oxobut-2-enoic Acid (5a). Yield: $26 \% ; \mathrm{mp} 177-178^{\circ} \mathrm{C}$. IR (Nujol): $\mathrm{v} \mathrm{cm}^{-1}$ $1660(\mathrm{C}=\mathrm{O}), 1730(\mathrm{C}=\mathrm{O}$ acid $) .{ }^{1} \mathrm{H}$ NMR $\left(\mathrm{CDCl}_{3}+\mathrm{DMSO} \mathrm{d}_{6}\right)$ : 


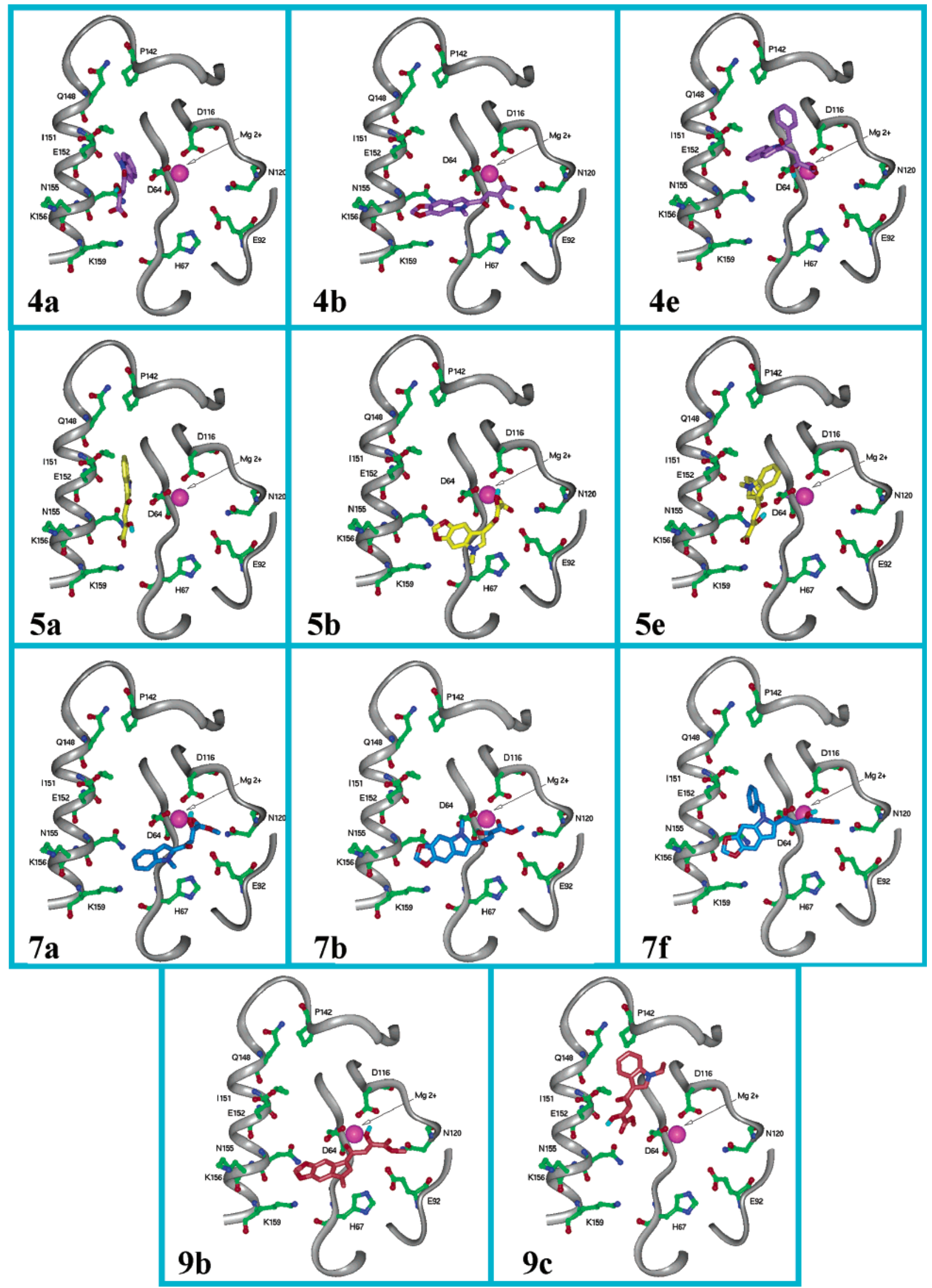

Figure 5. Predicted bound conformation of compounds $\mathbf{4 a , b}, \mathbf{e}$ (violet), $\mathbf{5 a}, \mathbf{b}, \mathbf{e}$ (yellow), $\mathbf{7 a}, \mathbf{b}, \mathbf{f}$ (cyan), and $\mathbf{9 b , \mathbf { c }}$ (red) inside the HIV-1 IN active site. The gray ribbon model shows the active site region while the ball-and-stick models represent prominent amino acid residues. The $\mathrm{Mg}^{2+}$ ion is represented by the magenta sphere. 
Table 4. GOLD Fitness Scores, H-Bonding I nteractions, and the HIV-I IN Active Site Amino Acid Residues Interacting with the Indole $\beta$-Diketo Acid Derivatives $\mathbf{4 a - 9 c ^ { a }}$<smiles>[X]OC(=O)/C(O)=C/C(=O)c1cc2ccccc2n1[R]</smiles>

$\mathbf{a}, \mathbf{c}, \mathbf{e}$

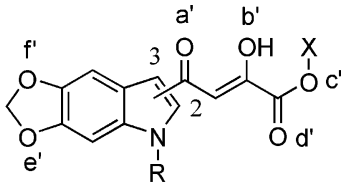

$\mathbf{b}, \mathbf{d}, \mathbf{f}$

a, b: $\mathrm{R}=\mathrm{CH}_{3} ; \mathbf{c}, \mathbf{d}: \mathrm{R}=\mathrm{CH}_{2} \mathrm{CH}_{3} ; \mathbf{e}, \mathbf{f}: \mathrm{R}=\mathrm{Bn}$

7, 9: $\mathrm{X}=\mathrm{CH}_{3} ; 4,7: 2-\mathrm{CO} ; 5,9: 3-\mathrm{CO}$

\begin{tabular}{|c|c|c|c|}
\hline compd & GOLD score & H-bonding interactions $(\AA)$ & interacting amino acid residues \\
\hline $\begin{array}{l}\mathbf{4 a} \\
\mathbf{4 b}\end{array}$ & $\begin{array}{l}36.31 \\
46.43\end{array}$ & 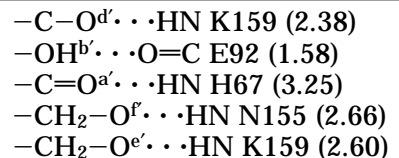 & $\begin{array}{l}\text { K159, N155, I 151, V77, V75, D64, Q62 } \\
\text { K159, K156, N155, E92, H67, T66, D64 }\end{array}$ \\
\hline $\begin{array}{l}\text { 4c } \\
\mathbf{4 d}\end{array}$ & $\begin{array}{l}39.74 \\
46.97\end{array}$ & 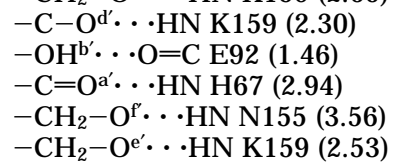 & $\begin{array}{l}\text { K159, N155, I 151, V77, V75, D64, Q62 } \\
\text { K 159, N155, K156, N155, E92, H67, T66, D64 }\end{array}$ \\
\hline 4 e & 52.75 & $\begin{array}{l}-\mathrm{OH}^{\mathrm{b}} \cdots \mathrm{O}=\mathrm{C} \mathrm{D} 64(2.61) \\
-\mathrm{OH}^{\mathrm{b}^{\prime}} \cdot \mathrm{O}=\mathrm{C} \text { C65 (3.49) }\end{array}$ & H114, D116,C65, D64, Q62 \\
\hline $\mathbf{4 f}$ & 50.02 & $\begin{array}{l}-\mathrm{OH}^{\mathrm{b}^{\prime} \ldots \mathrm{O}}=\mathrm{C} \text { D64 (3.02) } \\
-\mathrm{OH}^{\mathrm{b}^{\prime} \ldots \mathrm{O}}=\mathrm{C} \text { C65 (3.83) }\end{array}$ & P142, I141, F139, D116, H114, C65, D64, Q62 \\
\hline $5 \mathbf{a}$ & 42.46 & $\begin{array}{l}-\mathrm{C}-\mathrm{O}^{\mathrm{d}^{\prime}} \cdot \cdots \cdot \mathrm{HN} \text { N } 155(2.18) \\
-\mathrm{C}-\mathrm{O}^{\mathrm{c}} \cdot \operatorname{HN} \mathrm{H} 159(1.69)\end{array}$ & K159, N155, E152, I151, T66, D64, Q62 \\
\hline $5 \mathbf{b}$ & 52.11 & $\begin{array}{l}-\mathrm{OH}^{b^{\prime}} \ldots \mathrm{O}=\mathrm{C} \text { D } 116(2.37) \\
-\mathrm{CH}_{2}-\mathrm{O}^{\prime} \cdots \cdot \mathrm{HN} N 155(4.05) \\
-\mathrm{CH}_{2}-\mathrm{O}^{\prime} \cdot \mathrm{HN} \text { K } 159(2.38)\end{array}$ & K159, K156, N155, D116, E92, H67, T66, D64 \\
\hline 5c & 44.44 & 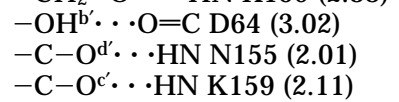 & K159, N155, E152, I151, T66, D64, Q62 \\
\hline $5 d$ & 52.72 & 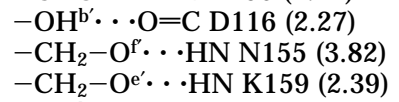 & K159, K156, N155, D116, E92, H67, T66, D64 \\
\hline $5 \mathbf{e}$ & 53.04 & 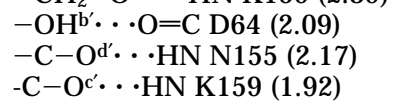 & K159, N155, I 151, V77, V75, D64, Q62 \\
\hline $\begin{array}{l}7 \mathbf{a} \\
\mathbf{7 b}\end{array}$ & $\begin{array}{l}40.89 \\
47.52\end{array}$ & $\begin{array}{l}-\mathrm{OH}^{b^{\prime}} \cdot \mathrm{OO}=\mathrm{C} \text { C65 (1.67) } \\
-\mathrm{CH}_{2}-\mathrm{O}^{\mathrm{f}^{\prime}} \cdot \mathrm{HN} \text { N } 155(1.68) \\
-\mathrm{CH}_{2}-\mathrm{O}^{e^{\prime}} \cdot \mathrm{HN} \text { K } 159(2.94)\end{array}$ & $\begin{array}{l}\text { K159, N155, F121, N120, E92, H67, T66, D64 } \\
\text { K159, K156, N155, E92, H67, T66, C65, D64 }\end{array}$ \\
\hline 7d & 46.06 & $\begin{array}{l}-\mathrm{OH}^{\mathrm{b}^{\prime}} \cdot \mathrm{O} \mathrm{O}=\mathrm{C} \mathrm{C} 65(1.58) \\
-\mathrm{CH}_{2}-\mathrm{O}^{\prime} \cdots \cdot \mathrm{HN} \text { N } 155(3.25) \\
-\mathrm{CH}_{2}-\mathrm{O}^{e} \cdot \cdots \mathrm{HN} \text { K } 159(1.73)\end{array}$ & K159, K156, N155, E92, H67, T66, C65, D64 \\
\hline $\begin{array}{l}7 f \\
9 b\end{array}$ & $\begin{array}{l}52.64 \\
52.78\end{array}$ & 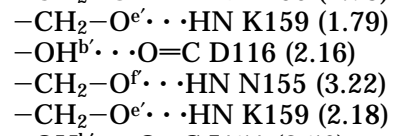 & $\begin{array}{l}\text { K159, K156, N155, E152, I151, E92, H67, T66, C65, D64, Q62 } \\
\text { K159, K156, N155, N120, D116 E92, H67, T66, C65, D64 }\end{array}$ \\
\hline 9c & 41.07 & $\begin{array}{l}-\mathrm{OH}^{\mathrm{b}^{\prime}} \cdot \mathrm{O}=\mathrm{C} \text { I } 151(2.56) \\
-\mathrm{C}-\mathrm{O}^{c} \cdot \operatorname{HN} \text { Q62 (3.55) }\end{array}$ & N155, E152, I151, Q148, P142, I141, D116, H114, D64, Q62 \\
\hline
\end{tabular}

a The superscript letter indicates the position of the $\mathrm{H}$-bond donor or acceptor atom of compounds $\mathbf{4 a - 9 c}$. Compounds $\mathbf{4 a - 5 e}$ were modeled in their monoanionic carboxylate form.

$\delta 8.31-8.26(1 \mathrm{H}, \mathrm{m}, \mathrm{Ar}-\mathrm{H}), 7.95(1 \mathrm{H}, \mathrm{s}, \mathrm{Ar}-\mathrm{H}), 7.32-7.45$ $(3 \mathrm{H}, \mathrm{m}, \mathrm{Ar}-\mathrm{H}+\mathrm{HC}=\mathrm{C}), 6.94(1 \mathrm{H}, \mathrm{s}, \mathrm{Ar}-\mathrm{H}), 3.89(3 \mathrm{H}, \mathrm{s}$, $\left.\mathrm{NCH}_{3}\right), 2.45-1.50$ (1H, bs, $\left.\mathrm{COOH}\right) . \mathrm{MS}: \mathrm{m} / \mathrm{z} 245\left(\mathrm{M}^{+}, 8\right), 157$ (base). Anal. $\left(\mathrm{C}_{13} \mathrm{H}_{11} \mathrm{NO}_{4}\right) \mathrm{C}, \mathrm{H}, \mathrm{N}$.

2-Hydroxy-4-(5-methyl-5H-[1,3]dioxolo[4,5-f]indol-7yl)-4-oxobut-2-enoic Acid (5b). Y ield: 34\%; mp 193-195 ${ }^{\circ} \mathrm{C}$. IR (Nujol): $\mathrm{V} \mathrm{cm}^{-1} 1620$ ( $\left.\mathrm{C}=\mathrm{O}\right), 1750$ ( $\mathrm{C}=\mathrm{O}$ acid). ${ }^{1} \mathrm{H} \mathrm{NMR}$ $\left(\mathrm{CDCl}_{3}+\mathrm{DMSO}_{-} \mathrm{d}_{6}\right): \delta 7.76(1 \mathrm{H}, \mathrm{s}, \mathrm{Ar}-\mathrm{H}), 7.64(\mathrm{H}, \mathrm{s}, \mathrm{Ar}-$ $\mathrm{H}), 7.46(1 \mathrm{H}, \mathrm{S}, \mathrm{Ar}-\mathrm{H}), 6.81(1 \mathrm{H}, \mathrm{S}, \mathrm{HC}=\mathrm{C}), 5.99(2 \mathrm{H}, \mathrm{s}$, $\left.\mathrm{OCH}_{2} \mathrm{O}\right), 3.79\left(3 \mathrm{H}, \mathrm{s}, \mathrm{NCH}_{3}\right), 3.65-3.15(1 \mathrm{H}, \mathrm{bs}, \mathrm{COOH}) . \mathrm{MS}:$ $\mathrm{m} / \mathrm{z} 289\left(\mathrm{M}^{+}, 6\right), 201$ (base). Anal. $\left(\mathrm{C}_{14} \mathrm{H}_{11} \mathrm{NO}_{6}\right) \mathrm{C}, \mathrm{H}, \mathrm{N}$.

4-(1-Ethyl-1H-indol-3-yl)-2-hydroxy-4-oxobut-2-enoic Acid (5c). Yield: $56 \% ; \mathrm{mp} 145-146^{\circ} \mathrm{C}$. IR (Nujol): $\mathrm{v} \mathrm{cm}^{-1} 1650$ $(\mathrm{C}=\mathrm{O}), 1720\left(\mathrm{C}=\mathrm{O}\right.$ acid). ${ }^{1} \mathrm{H}$ NMR $\left(\mathrm{CDCl}_{3}\right): \delta 8.32-8.28(1 \mathrm{H}$, $\mathrm{m}, \mathrm{Ar}-\mathrm{H}), 8.00(\mathrm{H}, \mathrm{s}, \mathrm{Ar}-\mathrm{H}), 7.55-7.31(3 \mathrm{H}, \mathrm{m}, \mathrm{Ar}-\mathrm{H}+$ $\mathrm{HC}=\mathrm{C}), 6.94(\mathrm{H}, \mathrm{s}, \mathrm{Ar}-\mathrm{H}), 4.26\left(2 \mathrm{H}, \mathrm{q}, \mathrm{J} 7.0 \mathrm{~Hz}, \mathrm{CH}_{2}\right), 4.20$ $3.90(1 \mathrm{H}$, bs, $\mathrm{COOH}), 1.57\left(3 \mathrm{H}, \mathrm{t}, \mathrm{J} 7.0 \mathrm{~Hz}, \mathrm{CH}_{3}\right) . \mathrm{MS}: \mathrm{m} / \mathrm{z}$ $259\left(\mathrm{M}^{+}, 3\right), 171$ (base). Anal. $\left(\mathrm{C}_{14} \mathrm{H}_{13} \mathrm{NO}_{4}\right) \mathrm{C}, \mathrm{H}, \mathrm{N}$.
4-(5-E thyl-5H-[1,3]dioxolo[4,5-f]indol-7-yl)-2-hydroxy4-oxobut-2-enoic Acid (5d). Y ield: 32\%; mp 200-201 ${ }^{\circ} \mathrm{C}$. IR (Nujol): $\mathrm{v} \mathrm{cm}^{-1} 1620(\mathrm{C}=\mathrm{O}), 1700\left(\mathrm{C}=\mathrm{O}\right.$ acid). ${ }^{1} \mathrm{H} \mathrm{NMR}$ $\left(\mathrm{CDCl}_{3}+\mathrm{DMSO}_{\mathrm{d}}\right): \delta 7.88(1 \mathrm{H}, \mathrm{s}, \mathrm{Ar}-\mathrm{H}), 7.75(1 \mathrm{H}, \mathrm{d}$, $\mathrm{HC}=\mathrm{C}), 7.49(\mathrm{H}, \mathrm{s}, \mathrm{Ar}-\mathrm{H}), 6.88(\mathrm{H}, \mathrm{s}, \mathrm{Ar}-\mathrm{H}), 6.00(2 \mathrm{H}, \mathrm{s}$ $\left.\mathrm{OCH}_{2} \mathrm{O}\right), 4.18\left(2 \mathrm{H}, \mathrm{q}, \mathrm{J} 7.2 \mathrm{~Hz}, \mathrm{CH}_{2}\right), 4.20-3.00(1 \mathrm{H}, \mathrm{bs}$, $\mathrm{COOH}), 1.50\left(3 \mathrm{H}, \mathrm{t}, \mathrm{J} 7.2 \mathrm{~Hz}, \mathrm{CH}_{3}\right) . \mathrm{MS}: \mathrm{m} / \mathrm{z} 303\left(\mathrm{M}^{+}, 4\right), 215$ (base). Anal. $\left(\mathrm{C}_{15} \mathrm{H}_{13} \mathrm{NO}_{6} \cdot 0.05 \mathrm{H}_{2} \mathrm{O}\right) \mathrm{C}, \mathrm{H}, \mathrm{N}$.

4-(1-Benzyl-1H-indol-3-yl)-2-hydroxy-4-oxobut-2-enoic Acid (5e). Yield: $69 \%$; $\mathrm{mp} 181-182{ }^{\circ} \mathrm{C}$. IR (Nujol): $\mathrm{v} \mathrm{cm}^{-1}$ $1620(\mathrm{C}=\mathrm{O}), 1700\left(\mathrm{C}=\mathrm{O}\right.$ acid). ${ }^{1} \mathrm{H} \mathrm{NMR}\left(\mathrm{CDCl}_{3}+\mathrm{DMSO}-\mathrm{d}_{6}\right)$ : $\delta 8.39(1 \mathrm{H}, \mathrm{d}, \mathrm{Ar}-\mathrm{H}), 8.11(1 \mathrm{H}, \mathrm{s}, \mathrm{Ar}-\mathrm{H}), 7.49-7.21(6 \mathrm{H}, \mathrm{m}$, $\mathrm{Ar}-\mathrm{H}+\mathrm{HC}=\mathrm{C}), 7.22(1 \mathrm{H}, \mathrm{s}, \mathrm{Ar}-\mathrm{H}), 6.90(1 \mathrm{H}, \mathrm{s}, \mathrm{HC}=\mathrm{C}), 6.89$ $(1 \mathrm{H}, \mathrm{s}, \mathrm{Ar}-\mathrm{H}), 5.42\left(2 \mathrm{H}, \mathrm{s}, \mathrm{CH}_{2}\right), 3.98-3.75(1 \mathrm{H}, \mathrm{bs}, \mathrm{COOH})$. MS: $\mathrm{m} / \mathrm{z} 321$ ( $\left.\mathrm{M}^{+}, 9\right), 90$ (base). Anal. $\left(\mathrm{C}_{19} \mathrm{H}_{15} \mathrm{NO}_{4}\right) \mathrm{C}, \mathrm{H}, \mathrm{N}$.

General Procedure for the Preparations of Indole $\boldsymbol{\beta}$-Diketo Esters ( $7 \mathbf{a}-\mathbf{f}$ and $\mathbf{9 a}-\mathbf{e})$. A solution of an appropriate alkylacetylindole $(\mathbf{6 a}-\mathbf{f}$ and $\mathbf{8 a}-\mathbf{e})(5.4 \mathrm{mmol})$ and di ethyl- 
Table 5. Interactions of Indole $\beta$-Diketo Acids with $\mathrm{Mg}^{2+} \mathrm{Ion}^{\mathrm{a}}$

\begin{tabular}{|c|c|c|c|}
\hline compd & $\mathrm{Mg}^{2+}$ interactions $(\AA)$ & compd & $\mathrm{Mg}^{2+}$ interactions $(\AA)$ \\
\hline $\begin{array}{l}\mathbf{4 f} \\
5 \mathbf{a} \\
5 \mathbf{b} \\
5 c \\
5 d\end{array}$ & 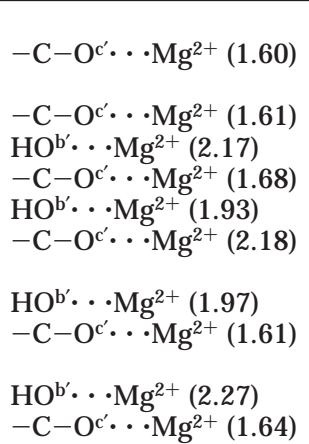 & $\begin{array}{l}5 e \\
7 a \\
7 b \\
7 d \\
7 f\end{array}$ & 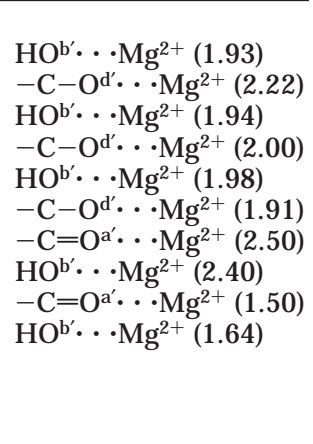 \\
\hline
\end{tabular}

a The superscript letter indicates the atom on a compound that is involved in a coordinate bonding interaction with the $\mathrm{Mg}^{2+}$ ion. See Table 4 for $\mathbf{4 a}-\mathbf{9 c}$.

oxalate (1.3 equiv) in methanol $(30 \mathrm{~mL})$ or THF $(30 \mathrm{~mL})$ was added to a solution of sodium methoxide (3.2 equiv) (generated from sodium in methanol). The mixture was refluxed under a nitrogen atmosphere for $4 \mathrm{~h}$ (or $24 \mathrm{~h}$ for compound 9e). After dilution with water, the solution was acidified with $1 \mathrm{~N} \mathrm{HCl}$. The yellow precipitate formed was filtered and purified by flash chromatography over silica gel using petroleum ether and ethyl acetate as eluent.

Methyl 2-Hydroxy-4-(1-methyl-1H-indol-2-yl)-4-oxobut2-enoate (7a). Yield: 55\%; $\mathrm{mp} 97-98^{\circ} \mathrm{C}$. IR (Nujol): $\mathrm{v} \mathrm{cm}^{-1}$ $1630(\mathrm{C}=\mathrm{O}), 1740(\mathrm{C}=\mathrm{O}$ ester $) .{ }^{1} \mathrm{H} N M R\left(\mathrm{CDCl}_{3}\right): \delta 7.70(1 \mathrm{H}$, $\mathrm{d}, \mathrm{Ar}-\mathrm{H}), 7.48-7-56(4 \mathrm{H}, \mathrm{m}, \mathrm{Ar}-\mathrm{H}), 7.07(1 \mathrm{H}, \mathrm{s}, \mathrm{HC}=\mathrm{C}), 4.13$ $\left(3 \mathrm{H}, \mathrm{s}, \mathrm{OCH}_{3}\right), 3.94\left(3 \mathrm{H}, \mathrm{s}, \mathrm{NCH}_{3}\right) . \mathrm{MS}: \mathrm{m} / \mathrm{z} 259\left(\mathrm{M}^{+}, 9\right), 172$ (base). Anal. $\left(\mathrm{C}_{14} \mathrm{H}_{13} \mathrm{NO}_{4}\right) \mathrm{C}, \mathrm{H}, \mathrm{N}$.

Methyl 2-Hydroxy-4-(5-methyl-5H-[1,3]dioxolo[4,5-f]indol-6-yl)-4-oxobut-2-enoate (7b). Yield: 46\%; mp $180^{\circ} \mathrm{C}$ (dec). IR (Nujol): $\mathrm{v} \mathrm{cm}^{-1} 1630(\mathrm{C}=\mathrm{O}), 1730\left(\mathrm{C}=\mathrm{O}\right.$ ester). ${ }^{1} \mathrm{H}$ NMR $\left(\mathrm{CDCl}_{3}\right): \delta 7.29(1 \mathrm{H}, \mathrm{s}, \mathrm{Ar}-\mathrm{H}), 6.98(2 \mathrm{H}, \mathrm{m}, \mathrm{Ar}-\mathrm{H}+$ $\mathrm{HC}=\mathrm{C}), 6.78(\mathrm{H}, \mathrm{s}, \mathrm{Ar}-\mathrm{H}), 6.01\left(2 \mathrm{H}, \mathrm{s}, \mathrm{OCH}_{2} \mathrm{O}\right), 4.06(3 \mathrm{H}, \mathrm{s}$, $\left.\mathrm{OCH}_{3}\right), 3.93\left(3 \mathrm{H}, \mathrm{s}, \mathrm{NCH}_{3}\right)$. MS: $\mathrm{m} / \mathrm{z} 303\left(\mathrm{M}^{+}, 6\right), 216$ (base). Anal. $\left(\mathrm{C}_{15} \mathrm{H}_{13} \mathrm{NO}_{6}\right) \mathrm{C}, \mathrm{H}, \mathrm{N}$.

Methyl 4-(1-ethyl-1H-indol-2-yl)-2-hydroxy-4-oxobut2-enoate (7c). Yield: $51 \%$; $\mathrm{mp} 103^{\circ} \mathrm{C}$ (dec). IR (Nujol): $\mathrm{v} \mathrm{cm}^{-1}$ $1615(\mathrm{C}=\mathrm{O}), 1720\left(\mathrm{C}=\mathrm{O}\right.$ ester). ${ }^{1} \mathrm{H} \mathrm{NMR}\left(\mathrm{CDCl}_{3}+\mathrm{DMSO} \mathrm{d}_{6}\right)$ : $\delta 7.71(1 \mathrm{H}, \mathrm{d}, \mathrm{Ar}-\mathrm{H}), 7.50-7.39(3 \mathrm{H}, \mathrm{m}, \mathrm{Ar}-\mathrm{H}), 7.23-7.15$ $(1 \mathrm{H}, \mathrm{m}, \mathrm{Ar}-\mathrm{H}), 7.09(1 \mathrm{H}, \mathrm{s}, \mathrm{CH}=\mathrm{H}), 4.65(2 \mathrm{H}, \mathrm{q}$, J $7.2 \mathrm{~Hz}$, $\left.\mathrm{CH}_{2}\right), 3.95\left(1 \mathrm{H}, \mathrm{s}, \mathrm{OCH}_{3}\right), 1.42\left(3 \mathrm{H}, \mathrm{t}, \mathrm{J} 7.2 \mathrm{~Hz}, \mathrm{CH}_{3}\right) . \mathrm{MS}: \mathrm{m} / \mathrm{z}$ $273\left(\mathrm{M}^{+}, 171\right), 4$ (base). Anal. $\left(\mathrm{C}_{15} \mathrm{H}_{15} \mathrm{NO}_{4}\right) \mathrm{C}, \mathrm{H}, \mathrm{N}$.

Methyl 4-(5-Ethyl-5H-[1,3]dioxolo[4,5-f]indol-6-yl)-2hydroxy-4-oxo-but-2-enoate (7d). Yield: 42\%; mp 170-172 ${ }^{\circ} \mathrm{C}$. IR (Nujol): $\mathrm{v} \mathrm{cm}^{-1} 1630$ (C=O), 1730 ( $\mathrm{C}=\mathrm{O}$ ester). ${ }^{1} \mathrm{H}$ NMR $\left(\mathrm{CDCl}_{3}+\mathrm{DMSO}_{-} \mathrm{d}_{6}\right): \delta 7.33(1 \mathrm{H}, \mathrm{s}, \mathrm{Ar}-\mathrm{H}), 6.97(2 \mathrm{H}, \mathrm{s}, \mathrm{Ar}-\mathrm{H}$ $+\mathrm{CH}=\mathrm{C}), 6.85(1 \mathrm{H}, \mathrm{s}, \mathrm{Ar}-\mathrm{H}), 6.02\left(2 \mathrm{H}, \mathrm{s}, \mathrm{OCH}_{2} \mathrm{O}\right), 4.56(2 \mathrm{H}$, q, J $\left.7.0 \mathrm{~Hz}, \mathrm{CH}_{2}\right), 3.92\left(3 \mathrm{H}, \mathrm{s}, \mathrm{OCH}_{3}\right), 1.38(3 \mathrm{H}, \mathrm{t}, \mathrm{J} 7.0 \mathrm{~Hz}$, $\mathrm{CH}_{3}$ ). MS: $\mathrm{m} / \mathrm{z} 317\left(\mathrm{M}^{+}, 7\right), 230$ (base). Anal. $\left(\mathrm{C}_{16} \mathrm{H}_{15} \mathrm{NO}_{6}\right) \mathrm{C}$, $\mathrm{H}, \mathrm{N}$.

Methyl 4-(1-Benzyl-1H-indol-2-yl)-2-hydroxy-4-oxo-but2-enoate (7e). Yield: $71 \% ; \mathrm{mp} 167{ }^{\circ} \mathrm{C}$ (dec). IR (Nujol): $\mathrm{v} \mathrm{cm}^{-1}$ $1640(\mathrm{C}=\mathrm{O}), 1710\left(\mathrm{C}=\mathrm{O}\right.$ ester). ${ }^{1} \mathrm{H}$ NMR $\left(\mathrm{CDCl}_{3}\right): \delta 7.62(1 \mathrm{H}$, $\mathrm{d}, \mathrm{Ar}-\mathrm{H}), 7.28-6.89(9 \mathrm{H}, \mathrm{m}, \mathrm{Ar}-\mathrm{H}+\mathrm{HC}=\mathrm{C}), 6.71(1 \mathrm{H}, \mathrm{s}, \mathrm{Ar}-$ $\mathrm{H}), 5.83\left(2 \mathrm{H}, \mathrm{s}, \mathrm{CH}_{2}\right), 3.67\left(3 \mathrm{H}, \mathrm{s}, \mathrm{OCH}_{3}\right) . \mathrm{MS}: \mathrm{m} / \mathrm{z} 335\left(\mathrm{M}^{+}\right.$, 7), 90 (base). Anal. $\left(\mathrm{C}_{20} \mathrm{H}_{17} \mathrm{NO}_{4} \cdot 0.50 \mathrm{H}_{2} \mathrm{O}\right) \mathrm{C}, \mathrm{H}, \mathrm{N}$.

Methyl 4-(5-Benzyl-5H-[1,3]dioxolo[4,5-f]indol-6-yl)-2hydroxy-4-oxo-but-2-enoate (7f). Yield: $72 \%$; mp $131{ }^{\circ} \mathrm{C}$ (dec). IR (Nujol): $v \mathrm{~cm}^{-1} 1630(\mathrm{C}=\mathrm{O}), 1750\left(\mathrm{C}=\mathrm{O}\right.$ ester). ${ }^{1 \mathrm{H}}$ NMR $\left(\mathrm{CDCl}_{3}+\mathrm{DMSO}_{-} \mathrm{d}_{6}\right): \delta 7.33-6.98(7 \mathrm{H}, \mathrm{m}, \mathrm{Ar}-\mathrm{H}), 6.81$ $(1 \mathrm{H}, \mathrm{s}, \mathrm{HC}=\mathrm{C}), 6.70(1 \mathrm{H}, \mathrm{s}, \mathrm{Ar}-\mathrm{H}), 5.95\left(2 \mathrm{H}, \mathrm{s}, \mathrm{OCH}_{2} \mathrm{O}\right), 5.83$ $\left(2 \mathrm{H}, \mathrm{s}, \mathrm{CH}_{2}\right), 3.82\left(3 \mathrm{H}, \mathrm{s}, \mathrm{CH}_{3}\right) . \mathrm{MS}: \mathrm{m} / \mathrm{z} 379\left(\mathrm{M}^{+}, 5\right), 90$ (base). Anal. $\left(\mathrm{C}_{21} \mathrm{H}_{17} \mathrm{NO}_{6}\right) \mathrm{C}, \mathrm{H}, \mathrm{N}$.

Methyl 2-Hydroxy-4-(1-methyl-1H-indol-3-yl)-4-oxobut-2-enoate (9a). Yield: $81 \%$; $\mathrm{mp} 174-175^{\circ} \mathrm{C}$. IR (Nujol): v cm ${ }^{-1} 1610(\mathrm{C}=\mathrm{O}), 1745(\mathrm{C}=\mathrm{O}$ ester $) .{ }^{1} \mathrm{H}$ NMR $\left(\mathrm{CDCl}_{3}\right): \delta$ 8.42-8.34 (1H, m, Ar-H ), $7.86(1 \mathrm{H}, \mathrm{s}, \mathrm{Ar}-\mathrm{H}), 7.42-7.30(3 \mathrm{H}$, $\mathrm{m}, \mathrm{Ar}-\mathrm{H}), 6.85(\mathrm{H}, \mathrm{s}, \mathrm{HC}=\mathrm{C}), 3.93\left(3 \mathrm{H}, \mathrm{s}, \mathrm{OCH}_{3}\right), 3.88(3 \mathrm{H}$, $\left.\mathrm{s}, \mathrm{NCH}_{3}\right), 2.10-1.55(1 \mathrm{H}, \mathrm{bs}, \mathrm{COOH}) . \mathrm{MS}: \mathrm{m} / \mathrm{z} 259\left(\mathrm{M}^{+}, 3\right)$, 157 (base). Anal. $\left(\mathrm{C}_{14} \mathrm{H}_{13} \mathrm{NO}_{4}\right) \mathrm{C}, \mathrm{H}, \mathrm{N}$.

Methyl 2-Hydroxy-4-(5-methyl-5H-[1,3]dioxolo[4,5-f]indol-7-yl)-4-oxo-but-2-enoate (9b). Y ield: 75\%; mp 165-164 ${ }^{\circ} \mathrm{C}$. IR (Nujol): $\mathrm{v} \mathrm{cm}^{-1} 1640(\mathrm{C}=\mathrm{O}), 1735$ ( $\mathrm{C}=\mathrm{O}$ ester). ${ }^{1} \mathrm{H}$ NMR $\left(\mathrm{CDCl}_{3}\right): \delta 7.81(1 \mathrm{H}, \mathrm{s}, \mathrm{Ar}-\mathrm{H}), 7.69(1 \mathrm{H}, \mathrm{s}, \mathrm{Ar}-\mathrm{H}), 7.55(1 \mathrm{H}$, $\mathrm{s}, \mathrm{Ar}-\mathrm{H}), 6.79(\mathrm{H}, \mathrm{s}, \mathrm{CH}=\mathrm{C}), 6.01\left(2 \mathrm{H}, \mathrm{s}, \mathrm{OCH}_{2} \mathrm{O}\right), 3.93(3 \mathrm{H}$, $\left.\mathrm{s}, \mathrm{OCH}_{3}\right), 3.80\left(3 \mathrm{H}, \mathrm{s}, \mathrm{NCH}_{3}\right) . \mathrm{MS}: \mathrm{m} / \mathrm{z} 303\left(\mathrm{M}^{+}, 7\right), 201$ (base). Anal. $\left(\mathrm{C}_{15} \mathrm{H}_{13} \mathrm{NO}_{6}\right) \mathrm{C}, \mathrm{H}, \mathrm{N}$.

Methyl 4-(1-Ethyl-1H-indol-3-yl)-2-hydroxy-4-oxo-but2-enoate (9c). Yield: $59 \%$; $\mathrm{mp} 159-161^{\circ} \mathrm{C}$. IR (Nujol): $\mathrm{v} \mathrm{cm}^{-1}$ $1610(\mathrm{C}=\mathrm{O}), 1740(\mathrm{C}=\mathrm{O}$ ester $) .{ }^{1} \mathrm{H}$ NMR $\left(\mathrm{CDCl}_{3}\right): \delta 8.41-8.36$ $(1 \mathrm{H}, \mathrm{m}, \mathrm{Ar}-\mathrm{H}), 7.93(\mathrm{H}, \mathrm{s}, \mathrm{Ar}-\mathrm{H}), 7.58-7.28(3 \mathrm{H}, \mathrm{m}, \mathrm{Ar}-$ $\mathrm{H}), 6.87(1 \mathrm{H}, \mathrm{s}, \mathrm{HC}=\mathrm{C}), 4.28\left(2 \mathrm{H}, \mathrm{q}, \mathrm{J} 7.4 \mathrm{~Hz}, \mathrm{NCH}_{2}\right), 3.94$ $\left(3 \mathrm{H}, \mathrm{s}, \mathrm{OCH}_{3}\right), 1.57\left(3 \mathrm{H}, \mathrm{t}, \mathrm{J} 7.4 \mathrm{~Hz}, \mathrm{CH}_{3}\right) . \mathrm{MS}: \mathrm{m} / \mathrm{z} 273\left(\mathrm{M}^{+}\right.$, 7), 171 (base). Anal. $\left(\mathrm{C}_{15} \mathrm{H}_{15} \mathrm{NO}_{4}\right) \mathrm{C}, \mathrm{H}, \mathrm{N}$

Methyl 4-(5-Ethyl-5H-[1,3]dioxolo[4,5-f]indol-7yl)-2-hydroxy-4-oxo-but-2-enoate (9d). Y ield: $32 \%$; $\mathrm{mp} 154-155^{\circ} \mathrm{C}$. IR (Nujol): $v \mathrm{~cm}^{-1} 1630(\mathrm{C}=\mathrm{O}), 1710\left(\mathrm{C}=\mathrm{O}\right.$ ester). ${ }^{1} \mathrm{H}$ NMR $\left(\mathrm{CDCl}_{3}\right): \delta 7.81(1 \mathrm{H}, \mathrm{s}, \mathrm{Ar}-\mathrm{H}), 7.76(1 \mathrm{H}, \mathrm{s}, \mathrm{Ar}-\mathrm{H}), 6.82(1 \mathrm{H}$, $\mathrm{s}, \mathrm{HC}=\mathrm{C}), 6.79(\mathrm{H}, \mathrm{s}, \mathrm{Ar}-\mathrm{H}), 6.01\left(2 \mathrm{H}, \mathrm{s}, \mathrm{OCH}_{2} \mathrm{O}\right), 4.13(2 \mathrm{H}$, q, J $\left.7.0 \mathrm{~Hz}, \mathrm{CH}_{2}\right), 3.93\left(3 \mathrm{H}, \mathrm{s}, \mathrm{OCH}_{3}\right), 1.53(3 \mathrm{H}, \mathrm{t}, \mathrm{J} 7.0 \mathrm{~Hz}$, $\left.\mathrm{CH}_{3}\right)$. MS: $\mathrm{m} / \mathrm{z} 317\left(\mathrm{M}^{+}, 4\right), 215$ (base). Anal. $\left(\mathrm{C}_{16} \mathrm{H}_{15} \mathrm{NO}_{6}\right.$. $\left.0.70 \mathrm{H}_{2} \mathrm{O}\right) \mathrm{C}, \mathrm{H}, \mathrm{N}$.

Methyl 4-(1-Benzyl-1H-indol-3-yl)-2-hydroxy-4-oxo-but2-enoate (9e). Yield: $37 \% ; \mathrm{mp} 178-179{ }^{\circ} \mathrm{C}$. IR (Nujol): $\mathrm{v} \mathrm{cm}^{-1}$ $1610(\mathrm{C}=\mathrm{O}), 1730(\mathrm{C}=\mathrm{O}$ ester $) .{ }^{1} \mathrm{H}$ NMR $\left(\mathrm{CDCl}_{3}\right): \delta 8.49-8.42$ $(1 \mathrm{H}, \mathrm{m}, \mathrm{Ar}-\mathrm{H}), 7.91(\mathrm{H}, \mathrm{s}, \mathrm{Ar}-\mathrm{H}), 7.40-7.32(8 \mathrm{H}, \mathrm{m}, \mathrm{Ar}-$ $\mathrm{H}), 6.84(\mathrm{H}, \mathrm{s}, \mathrm{HC}=\mathrm{C}), 5.39\left(2 \mathrm{H}, \mathrm{s}, \mathrm{CH}_{2}\right), 3.92\left(3 \mathrm{H}, \mathrm{s}, \mathrm{OCH}_{3}\right)$. MS: $\mathrm{m} / \mathrm{z} 335\left(\mathrm{M}^{+}, 5\right), 90$ (base). Anal. $\left(\mathrm{C}_{20} \mathrm{H}_{17} \mathrm{NO}_{4}\right) \mathrm{C}, \mathrm{H}, \mathrm{N}$.

Preparation of N-Alkylindoles $(8 \mathrm{a}, \mathrm{C}, \mathrm{e} 12-15,17$, and 18). Anhydrous DMSO (20 mL) was added to $\mathrm{KOH}$ (4 equiv, crushed pellets), and the mixture was stirred at room temperature for $5 \mathrm{~min}$. An appropriate indole (10, 11, 16, and 25) (10 mmol) was then added, and the mixture was stirred at room temperature for 45-60 min. An appropriate alkyl halide ( 2 equiv) was added, and the mixture was stirred at room temperature for $45-60 \mathrm{~min}$. The progress of reaction was monitored by TLC throughout the course of the experiment. Then, water was added and the white precipitate that formed was filtered and washed with water. The compounds that did not precipitate were extracted from the aqueous solution with diethyl ether. The organic layer was washed with water and dried over $\mathrm{Na}_{2} \mathrm{SO}_{4}$, and the solvent was removed in vacuo to give the desired final product as a solid or oil.

1-(1-Methyl-1H-indol-3-yl )ethanone (8a). ${ }^{43}$ Y ield: $57 \%$; $\mathrm{mp}$ 107-108 ${ }^{\circ} \mathrm{C}$. IR (Nujol): $\mathrm{v} \mathrm{cm}^{-1} 1640$ (C=O). ${ }^{1} \mathrm{H} N M R$ $\left(\mathrm{CDCl}_{3}\right): \delta 8.45-8.35(1 \mathrm{H}, \mathrm{m}, \mathrm{Ar}-\mathrm{H}), 7.69(1 \mathrm{H}, \mathrm{s}, \mathrm{Ar}-\mathrm{H})$, 7.42-7.28 (3H, m, Ar-H), $3.85\left(3 \mathrm{H}, \mathrm{s}, \mathrm{NCH}_{3}\right), 2.51(3 \mathrm{H}, \mathrm{s}$, $\left.\mathrm{CH}_{3}\right) . \mathrm{MS}: \mathrm{m} / \mathrm{z} 173\left(\mathrm{M}^{+}, 100\right), 173$ (base).

1-(1-Ethyl-1H-indol-3-yl)ethanone (8c). ${ }^{44}$ Y ield: $69 \%$; $\mathrm{mp}$ 87-89 ${ }^{\circ} \mathrm{C}$. IR (Nujol): $\mathrm{v} \mathrm{cm}{ }^{-1} 1630(\mathrm{C}=\mathrm{O}) .{ }^{1} \mathrm{H} \mathrm{NMR}\left(\mathrm{CDCl}_{3}\right)$ : $\delta$ 8.45-8.35 (1H, m, Ar-H), $7.78(1 \mathrm{H}, \mathrm{s}, \mathrm{Ar}-\mathrm{H}), 7.45-7.25$ $(3 \mathrm{H}, \mathrm{m}, \mathrm{Ar}-\mathrm{H}), 4.25\left(2 \mathrm{H}, \mathrm{q}\right.$, J $\left.7.2 \mathrm{~Hz}, \mathrm{CH}_{2}\right), 1.57(3 \mathrm{H}, \mathrm{t}, \mathrm{J} 7.2$ $\mathrm{Hz}, \mathrm{CH}_{3}$ ). MS: m/z $187\left(\mathrm{M}^{+}, 62\right), 172$ (base).

1-(1-Benzyl-1H-indol-3-yl)ethanone (8e).43 Y ield: 67\%; $\mathrm{mp}$ 109-110 ${ }^{\circ} \mathrm{C}$. IR (Nujol): $\mathrm{v} \mathrm{cm}^{-1} 1630(\mathrm{C}=\mathrm{O})$. ${ }^{1} \mathrm{H}$ NMR $\left(\mathrm{CDCl}_{3}\right): \delta 8.43-8.37(1 \mathrm{H}, \mathrm{m}, \mathrm{Ar}-\mathrm{H}), 7.77(\mathrm{H}, \mathrm{s}, \mathrm{Ar}-\mathrm{H})$, 7.40-7.16 (8H, m, Ar-H ), $5.35\left(2 \mathrm{H}, \mathrm{s}, \mathrm{CH}_{2}\right), 2.52\left(3 \mathrm{H}, \mathrm{s}, \mathrm{CH}_{3}\right)$. MS: $\mathrm{m} / \mathrm{z} 249\left(\mathrm{M}^{+}, 43\right), 91$ (base).

Methyl 1-Methyl-1H-indole-2-carboxylate (12). ${ }^{45}$ Y i eld: 93\%; mp 99-101 ${ }^{\circ} \mathrm{C}$ (dec). IR (Nujol): $\mathrm{v} \mathrm{cm}^{-1} 1710(\mathrm{C}=\mathrm{O})$. ${ }^{1} \mathrm{H}$ NMR $\left(\mathrm{CDCl}_{3}\right): \delta 7.72(1 \mathrm{H}, \mathrm{d}, \mathrm{Ar}-\mathrm{H}), 7.42-7.35(3 \mathrm{H}, \mathrm{m}, \mathrm{Ar}-$ $\mathrm{H}), 7.20-7.10(1 \mathrm{H}, \mathrm{m}, \mathrm{Ar}-\mathrm{H}), 4.06\left(3 \mathrm{H}, \mathrm{s}, \mathrm{OCH}_{3}\right), 3.90(3 \mathrm{H}, \mathrm{s}$, $\left.\mathrm{OCH}_{3}\right)$. MS: m/z $189\left(\mathrm{M}^{+}, 100\right), 189$ (base).

Methyl 5-Methyl-5H-[1,3]dioxolo[4,5-f]indole-6-carboxylate (13). Yield: $89 \% ; \mathrm{mp} 166{ }^{\circ} \mathrm{C}$. IR (Nujol): $\mathrm{v} \mathrm{cm}^{-1} 1700$ $(\mathrm{C}=\mathrm{O})$. ${ }^{\mathrm{H}} \mathrm{NMR}\left(\mathrm{CDCl}_{3}\right): \delta 7.13(\mathrm{lH}, \mathrm{s}, \mathrm{Ar}-\mathrm{H}), 6.95(1 \mathrm{H}, \mathrm{s}$, $\mathrm{Ar}-\mathrm{H}), 6.75(\mathrm{H}, \mathrm{s}, \mathrm{Ar}-\mathrm{H}), 5.95\left(2 \mathrm{H}, \mathrm{s}, \mathrm{OCH}_{2} \mathrm{O}\right), 3.96(3 \mathrm{H}, \mathrm{s}$, $\left.\mathrm{OCH}_{3}\right), 3.85\left(3 \mathrm{H}, \mathrm{s}, \mathrm{NCH}_{3}\right) . \mathrm{MS}: \mathrm{m} / \mathrm{z} 233\left(\mathrm{M}^{+}, 100\right), 233$ (base).

Methyl 5-Ethyl-5H-[1,3]dioxolo[4,5-f]indole-6-carboxylate (14). Yield: $91 \%$; $\mathrm{mp} 158-159{ }^{\circ} \mathrm{C}$. IR (Nujol): $\mathrm{V} \mathrm{cm}^{-1}$ $1680(\mathrm{C}=\mathrm{O}) .{ }^{1} \mathrm{H} N M R\left(\mathrm{CDCl}_{3}\right): \delta 7.14(1 \mathrm{H}, \mathrm{s}, \mathrm{Ar}-\mathrm{H}), 6.96(1 \mathrm{H}$, $\mathrm{s}, \mathrm{Ar}-\mathrm{H}), 6.78(\mathrm{HH}, \mathrm{s}, \mathrm{Ar}-\mathrm{H}), 5.95\left(2 \mathrm{H}, \mathrm{s}, \mathrm{OCH}_{2} \mathrm{O}\right), 4.52(2 \mathrm{H}$, 
q, J $\left.7.4 \mathrm{~Hz}, \mathrm{CH}_{2}\right), 3.86\left(3 \mathrm{H}, \mathrm{s}, \mathrm{OCH}_{3}\right), 1.35(3 \mathrm{H}, \mathrm{t}$, J $7.4 \mathrm{~Hz}$, $\mathrm{CH}_{3}$ ). MS: $\mathrm{m} / \mathrm{z} 247\left(\mathrm{M}^{+}, 100\right), 247$ (base).

Methyl 5-Benzyl-5H-[1,3]dioxolo[4,5-f]indole-6-carboxylate (15). Y ield: $82 \%$; $\mathrm{mp} 142-144^{\circ} \mathrm{C}$. IR (Nujol): $\mathrm{v} \mathrm{cm}^{-1} 1700$ $(\mathrm{C}=\mathrm{O}) .{ }^{1} \mathrm{H} N M R\left(\mathrm{CDCl}_{3}\right): \delta 7.24(1 \mathrm{H}, \mathrm{s}, \mathrm{Ar}-\mathrm{H}), 7.21(1 \mathrm{H}, \mathrm{s}$, $\mathrm{Ar}-\mathrm{H}), 7.05-6.95(5 \mathrm{H}, \mathrm{m}, \mathrm{Ar}-\mathrm{H}), 6.71(\mathrm{H}, \mathrm{s}, \mathrm{Ar}-\mathrm{H}), 5.91$ $\left(2 \mathrm{H}, \mathrm{s}, \mathrm{OCH}_{2} \mathrm{O}\right), 5.75\left(2 \mathrm{H}, \mathrm{s}, \mathrm{CH}_{2}\right), 3.82\left(3 \mathrm{H}, \mathrm{s}, \mathrm{OCH}_{3}\right) . \mathrm{MS}$ : $\mathrm{m} / \mathrm{z} 309\left(\mathrm{M}^{+}, 76\right), 91$ (base).

Ethyl 1-Ethyl-1H-indole-2-carboxylate (17).46 Yield: $87 \%$; colorless oil. IR (Nujol): $\mathrm{v} \mathrm{cm}^{-1} 1710(\mathrm{C}=\mathrm{O})$. ${ }^{1} \mathrm{H} \mathrm{NMR}\left(\mathrm{CDCl}_{3}\right)$ : $\delta 7.68(1 \mathrm{H}, \mathrm{d}, \mathrm{Ar}-\mathrm{H}), 7.48-7.31(3 \mathrm{H}, \mathrm{m}, \mathrm{Ar}-\mathrm{H}), 7.13(1 \mathrm{H}, \mathrm{t}$, $\mathrm{Ar}-\mathrm{H}), 4.62\left(2 \mathrm{H}, \mathrm{q}, \mathrm{J} 7.0 \mathrm{~Hz}, \mathrm{CH}_{2}\right), 4.37(2 \mathrm{H}, \mathrm{q}, \mathrm{J} 7.0 \mathrm{~Hz}$, $\left.\mathrm{NCH}_{2}\right), 1.48\left(6 \mathrm{H}, \mathrm{m}, \mathrm{CH}_{3}\right)$. MS: $\mathrm{m} / \mathrm{z} 217\left(\mathrm{M}^{+}, 100\right), 217$ (base).

Ethyl 1-Benzyl-1H-indole-2-carboxylate (18). Yield: 91\%; $\mathrm{mp} 55-56{ }^{\circ} \mathrm{C}$. IR (Nujol): $\mathrm{v} \mathrm{cm}^{-1} 1720(\mathrm{C}=\mathrm{O})$. ${ }^{1} \mathrm{H} \quad \mathrm{NMR}$ $\left(\mathrm{CDCl}_{3}\right): \delta 7.70(1 \mathrm{H}, \mathrm{d}, \mathrm{Ar}-\mathrm{H}), 7.42-7.05(9 \mathrm{H}, \mathrm{m}, \mathrm{Ar}-\mathrm{H}), 5.84$ $\left(2 \mathrm{H}, \mathrm{s}, \mathrm{CH}_{2}\right), 4.31\left(2 \mathrm{H}, \mathrm{q}\right.$, J $\left.6.8 \mathrm{~Hz}, \mathrm{CH}_{2}\right), 1.34(3 \mathrm{H}, \mathrm{t}, \mathrm{J} 6.8 \mathrm{~Hz}$, $\left.\mathrm{CH}_{3}\right)$. MS: $\mathrm{m} / \mathrm{z} 279\left(\mathrm{M}^{+}, 57\right), 91$ (base).

Preparation of N-Alkyl-indol-2-carboxylic Acid (19af). A suspension of an appropriate ester $(\mathbf{1 2}-\mathbf{1 5}, \mathbf{1 7}, \mathbf{1 8})(5$ $\mathrm{mmol}$ ) in $12 \%$ aqueous $\mathrm{KOH}$ solution $(50 \mathrm{~mL}$ ) was stirred at reflux for $1 \mathrm{~h}$. The clear solution was poured into ice water and then acidified with $2 \mathrm{~N} \mathrm{HCl}$. A white precipitate was filtered off and washed with water.

1-Methyl-1H-indol-2-carboxylic Acid (19a). ${ }^{45}$ Y ield: $92 \%$; $\mathrm{mp} 210-211{ }^{\circ} \mathrm{C}$. IR (Nujol): $v \mathrm{~cm}^{-1} 1670(\mathrm{C}=\mathrm{O}) .{ }^{1} \mathrm{H}$ NMR $\left(\mathrm{CDCl}_{3}+\mathrm{DMSO}_{-} \mathrm{d}_{6}\right): \delta 7.66(1 \mathrm{H}, \mathrm{d}, \mathrm{Ar}-\mathrm{H}), 7.50-7.05(1 \mathrm{H}$, bs, $\mathrm{COOH}), 7.42-7.30(3 \mathrm{H}, \mathrm{m}, \mathrm{Ar}-\mathrm{H}), 7.15-7.05(1 \mathrm{H}, \mathrm{m}, \mathrm{Ar}-$ H), 4.08 (3H, s, $\left.\mathrm{CH}_{3}\right)$. MS: m/z $175\left(\mathrm{M}^{+}, 100\right), 175$ (base).

5-Methyl-5H-[1,3]dioxolo[4,5-f]indole-6-carboxylic Acid

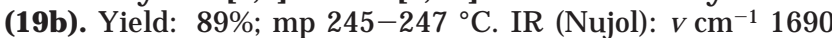
$(\mathrm{C}=\mathrm{O}) .{ }^{1} \mathrm{H}$ NMR $\left(\mathrm{CDCl}_{3}+\mathrm{DMSO}_{-} \mathrm{d}_{6}\right): \delta 7.07(1 \mathrm{H}, \mathrm{s}, \mathrm{Ar}-\mathrm{H})$, $6.96(1 \mathrm{H}, \mathrm{s}, \mathrm{Ar}-\mathrm{H}), 6.91(1 \mathrm{H}, \mathrm{s}, \mathrm{Ar}-\mathrm{H}), 5.97\left(2 \mathrm{H}, \mathrm{s}, \mathrm{OCH}_{2} \mathrm{O}\right)$, 4.50-2.80 (1H, bs, COOH), $3.97\left(3 \mathrm{H}, \mathrm{s}, \mathrm{CH}_{3}\right) . \mathrm{MS}: \mathrm{m} / \mathrm{z} 219$ $\left(\mathrm{M}^{+}, 100\right), 219$ (base).

1-Ethyl-1H-indole-2-carboxylic Acid (19c).47 Yield: 95\%; $\mathrm{mp}$ 177-179 ${ }^{\circ} \mathrm{C}$. IR (Nujol): $\mathrm{v} \mathrm{cm}^{-1} 1680(\mathrm{C}=\mathrm{O}) .{ }^{1} \mathrm{H}$ NMR $\left(\mathrm{CDCl}_{3}\right): \delta 8.10-6.90(1 \mathrm{H}, \mathrm{bs}, \mathrm{COOH}), 7.71(1 \mathrm{H}, \mathrm{d}, \mathrm{Ar}-\mathrm{H})$, 7.51-7.32 (3H, m, Ar-H), 7.21-7.10 (1H, m, Ar-H), $4.64(2 \mathrm{H}$ q, J $\left.7.0 \mathrm{~Hz}, \mathrm{CH}_{2}\right), 1.42\left(3 \mathrm{H}, \mathrm{t}, \mathrm{J} 7.0 \mathrm{~Hz}_{2} \mathrm{CH}_{3}\right) . \mathrm{MS}$ : m/z 189 $\left(\mathrm{M}^{+}, 75\right), 174$ (base).

5-Ethyl-5H-[1,3]dioxolo[4,5-f]indole-6-carboxylic Acid

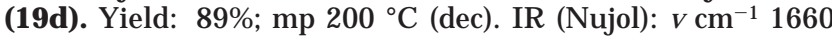
$(\mathrm{C}=\mathrm{O}) .{ }^{1} \mathrm{H} \mathrm{NMR}\left(\mathrm{CDCl}_{3}+\mathrm{DMSO} \mathrm{d}_{6}\right): \delta 7.11(1 \mathrm{H}, \mathrm{s}, \mathrm{Ar}-\mathrm{H})$, $6.95(1 \mathrm{H}, \mathrm{s}, \mathrm{Ar}-\mathrm{H}), 6.86(1 \mathrm{H}, \mathrm{s}, \mathrm{Ar}-\mathrm{H}), 5.97\left(2 \mathrm{H}, \mathrm{s}, \mathrm{OCH}_{2} \mathrm{O}\right)$, $5.20-4.30(1 \mathrm{H}, \mathrm{bs}, \mathrm{COOH}), 4.56\left(2 \mathrm{H}, \mathrm{q}, \mathrm{J} 6.8 \mathrm{~Hz}, \mathrm{CH}_{2}\right), 1.34$ $\left(3 \mathrm{H}, \mathrm{t}, \mathrm{J} 6.8 \mathrm{~Hz}, \mathrm{CH}_{3}\right)$. MS: m/z 233 (M+, 8), 189 (base).

1-Benzyl-1H-indole-2-carboxylic Acid (19e). ${ }^{48}$ Yield: 93\%; $\mathrm{mp}$ 194-196 ${ }^{\circ} \mathrm{C}$. IR (Nujol): $\mathrm{v} \mathrm{cm} \mathrm{cm}^{-1} 1660(\mathrm{C}=\mathrm{O}) .{ }^{1} \mathrm{H}$ NMR $\left(\mathrm{CDCl}_{3}+\mathrm{DMSO}_{-} \mathrm{d}_{6}\right): \delta 8.40-6.90(1 \mathrm{H}, \mathrm{bs}, \mathrm{COOH}), 7.68(1 \mathrm{H}$, $\mathrm{d}, \mathrm{Ar}-\mathrm{H}), 7.42-7.00(9 \mathrm{H}, \mathrm{m}, \mathrm{Ar}-\mathrm{H}), 5.86\left(2 \mathrm{H}, \mathrm{s}, \mathrm{CH}_{2}\right) . \mathrm{MS}$ : $\mathrm{m} / \mathrm{z} 251\left(\mathrm{M}^{+}, 29\right), 91$ (base).

5-Benzyl-5H-[1,3]dioxolo[4,5-f]indole-6-carboxylic Acid (19f). Y ield: 84\%; $\mathrm{mp} 224-226^{\circ} \mathrm{C}$. IR (Nujol): $\mathrm{v} \mathrm{cm} \mathrm{cm}^{-1} 1660$ (C= O). ${ }^{1} \mathrm{H} N M R\left(\mathrm{CDCl}_{3}\right): \delta 7.70-6.10(1 \mathrm{H}, \mathrm{bs}, \mathrm{COOH}), 7.23(1 \mathrm{H}$, $\mathrm{s}, \mathrm{Ar}-\mathrm{H}), 7.21(\mathrm{H}, \mathrm{s}, \mathrm{Ar}-\mathrm{H}), 7.18-6.98(5 \mathrm{H}, \mathrm{m}, \mathrm{Ar}-\mathrm{H}), 6.73$ $(1 \mathrm{H}, \mathrm{s}, \mathrm{Ar}-\mathrm{H}), 5.93\left(2 \mathrm{H}, \mathrm{s}, \mathrm{OCH}_{2} \mathrm{O}\right), 5.79\left(2 \mathrm{H}, \mathrm{s}, \mathrm{CH}_{2}\right) . \mathrm{MS}$ : $\mathrm{m} / \mathrm{z} 295\left(\mathrm{M}^{+}, 8\right), 91$ (base).

Synthesis of 2-Acetylindoles (6a-f). Under a nitrogen atmosphere, $\mathrm{CH}_{3} \mathrm{Li}$ (1.4 M in diethyl ether, $48 \mathrm{mmol}$ ) was slowly added to a suspension of an appropriate acid (19a-f) $(24 \mathrm{mmol})$ in anhydrous di ethyl ether $(30 \mathrm{~mL})$ and cooled to 0 ${ }^{\circ} \mathrm{C}$, and the mixture was refluxed for $1 \mathrm{~h}$. Additional $\mathrm{CH}_{3} \mathrm{Li}$ (1.4 $\mathrm{M}$ in diethyl ether, $48 \mathrm{mmol}$ ) was added at room temperature, and the mixture was refluxed for $4 \mathrm{~h}$. The reaction was quenched by the addition of saturated aqueous $\mathrm{NH}_{4} \mathrm{Cl}$, diluted, and extracted with diethyl ether. The organic layer was washed with water, dried over $\mathrm{Na}_{2} \mathrm{SO}_{4}$, and evaporated in vacuo to give the desired product as an oil or a solid.

1-(1-Methyl-1H-indol-2-yl)ethanone (6a). ${ }^{49}$ Y ield: $55 \%$; $\mathrm{mp}$ 68-70 ${ }^{\circ} \mathrm{C}$. IR (Nujol): $\mathrm{v} \mathrm{cm} \mathrm{cm}^{-1} 1665(\mathrm{C}=\mathrm{O}) .{ }^{1} \mathrm{H} N M R$ $\left(\mathrm{CDCl}_{3}\right): \delta 7.69(\mathrm{H}, \mathrm{d}, \mathrm{Ar}-\mathrm{H}), 7.37-7.14(4 \mathrm{H}, \mathrm{m}, \mathrm{Ar}-\mathrm{H}), 4.06$ $\left(3 \mathrm{H}, \mathrm{s}, \mathrm{CH}_{3}\right), 2.61\left(3 \mathrm{H}, \mathrm{s}, \mathrm{CH}_{3}\right) . \mathrm{MS}: \mathrm{m} / \mathrm{z} 173\left(\mathrm{M}^{+}, 100\right), 173$ (base).
1-(5-Methyl-5H-[1,3]dioxolo[4,5-f]indol-6-yl)ethanone (6b). Yield: $42 \% ; \mathrm{mp} 151-152^{\circ} \mathrm{C}$. IR (Nujol): $\mathrm{v} \mathrm{cm}^{-1} 1650(\mathrm{C}=$ O). ${ }^{1} \mathrm{H} N M R\left(\mathrm{CDCl}_{3}\right): \delta 7.13(1 \mathrm{H}, \mathrm{s}, \mathrm{Ar}-\mathrm{H}), 6.96(1 \mathrm{H}, \mathrm{s}, \mathrm{Ar}-$ $\mathrm{H}), 6.74(\mathrm{HH}, \mathrm{S}, \mathrm{Ar}-\mathrm{H}), 5.97\left(2 \mathrm{H}, \mathrm{S}, \mathrm{OCH}_{2} \mathrm{O}\right), 3.98(3 \mathrm{H}, \mathrm{s}$, $\left.\mathrm{NCH}_{3}\right), 2.52\left(3 \mathrm{H}, \mathrm{s}, \mathrm{CH}_{3}\right)$. MS: $\mathrm{m} / \mathrm{z} 217\left(\mathrm{M}^{+}, 65\right), 202$ (base).

1-(1-Ethyl-1H-indol-2-yl)ethanone (6c). ${ }^{50}$ Y ield: $65 \%$; mp 120-122 ${ }^{\circ} \mathrm{C}$. IR (Nujol): $\mathrm{V} \mathrm{cm}-1660(\mathrm{C}=\mathrm{O})$. ${ }^{1 \mathrm{H}} \mathrm{NMR}$ $\left(\mathrm{CDCl}_{3}\right): \delta 7.69(\mathrm{H}, \mathrm{d}, \mathrm{Ar}-\mathrm{H}), 7.41-7.05(4 \mathrm{H}, \mathrm{m}, \mathrm{Ar}-\mathrm{H}), 4.61$ $\left(2 \mathrm{H}, \mathrm{q}, \mathrm{J} 7.2 \mathrm{~Hz}, \mathrm{CH}_{2}\right), 2.62\left(3 \mathrm{H}, \mathrm{s}, \mathrm{CH}_{3}\right), 1.35(3 \mathrm{H}, \mathrm{t}, \mathrm{J} 7.2 \mathrm{~Hz}$, $\mathrm{CH}_{3}$ ). MS: $\mathrm{m} / \mathrm{z} 187\left(\mathrm{M}^{+}, 86\right), 172$ (base).

1-(5-Ethyl-5H-[1,3]dioxolo[4,5-f]indol-6-yl)ethanone (6d). Yield: 48\%; $\mathrm{mp} 132-135^{\circ} \mathrm{C}$. IR (Nujol): $\mathrm{v} \mathrm{cm}^{-1} 1650(\mathrm{C}=\mathrm{O})$. ${ }^{1} \mathrm{H}$ NMR $\left(\mathrm{CDCl}_{3}\right): \delta 7.15(1 \mathrm{H}, \mathrm{s}, \mathrm{Ar}-\mathrm{H}), 6.97(1 \mathrm{H}, \mathrm{s}, \mathrm{Ar}-\mathrm{H})$, $6.78(1 \mathrm{H}, \mathrm{s}, \mathrm{Ar}-\mathrm{H}), 5.97\left(2 \mathrm{H}, \mathrm{s}, \mathrm{OCH}_{2} \mathrm{O}\right), 4.51(2 \mathrm{H}, \mathrm{q}, \mathrm{J} 7.4$ $\left.\mathrm{Hz}, \mathrm{CH}_{2}\right), 2.54\left(3 \mathrm{H}, \mathrm{s}, \mathrm{CH}_{3}\right), 1.32\left(3 \mathrm{H}, \mathrm{t}, \mathrm{J} 7.4 \mathrm{~Hz}, \mathrm{CH}_{3}\right) . \mathrm{MS}$ : $\mathrm{m} / \mathrm{z} 231\left(\mathrm{M}^{+}, 100\right), 231$ (base).

1-(1-Benzyl-1H-indol-2-yl)ethanone (6e). ${ }^{24}$ Yield: $51 \%$; $\mathrm{mp} 126-128^{\circ} \mathrm{C}$. IR (Nujol): $\mathrm{v} \mathrm{cm}^{-1} 1650(\mathrm{C}=\mathrm{O}) .{ }^{1} \mathrm{H} N M R$ $\left(\mathrm{CDCl}_{3}\right): \delta 7.72(\mathrm{H}, \mathrm{d}, \mathrm{Ar}-\mathrm{H}), 7.41-7.05(9 \mathrm{H}, \mathrm{m}, \mathrm{Ar}-\mathrm{H}), 5.87$ $\left(2 \mathrm{H}, \mathrm{s}, \mathrm{CH}_{2}\right), 2.61\left(3 \mathrm{H}, \mathrm{s}, \mathrm{CH}_{3}\right) . \mathrm{MS}: \mathrm{m} / \mathrm{z} 249\left(\mathrm{M}^{+}, 35\right), 91$ (base).

1-(5-B enzyl-5H-[1,3]dioxolo-[4,5-f]indol-6-yl)ethanone (6f). Yield: $39 \%$; $\mathrm{mp} 141-142^{\circ} \mathrm{C}$. IR (N ujol): $\mathrm{v} \mathrm{cm} \mathrm{cm}^{-1} 1650$ $(\mathrm{C}=\mathrm{O})$. ${ }^{1} \mathrm{H} N M R\left(\mathrm{CDCl}_{3}\right): \delta 7.30-7.15(4 \mathrm{H}, \mathrm{m}, \mathrm{Ar}-\mathrm{H}), 7.08-$ $6.98(3 \mathrm{H}, \mathrm{m}, \mathrm{Ar}-\mathrm{H}), 6.71(\mathrm{H}, \mathrm{s}, \mathrm{Ar}-\mathrm{H}), 5.94\left(2 \mathrm{H}, \mathrm{s}, \mathrm{OCH}_{2} \mathrm{O}\right)$, $5.77\left(2 \mathrm{H}, \mathrm{s}, \mathrm{CH}_{2}\right), 2.53\left(3 \mathrm{H}, \mathrm{s}, \mathrm{CH}_{3}\right) . \mathrm{MS}: \mathrm{m} / \mathrm{z} 293\left(\mathrm{M}^{+}, 61\right), 91$ (base).

Preparation of Methyl Azidoacetate (22). ${ }^{42}$ A solution of methyl bromoacetate ( $85 \mathrm{mmol})$ and sodium azide $(90 \mathrm{mmol}$, 1.06 equiv) in DMF ( $20 \mathrm{~mL}$ ) was stirred at room temperature for $2.5 \mathrm{~h}$. After a white solid formed, an equivalent quantity of water was added and the resulting solution was extracted three times with diethyl ether. The organic layer was washed six times with water and dried over $\mathrm{Na}_{2} \mathrm{SO}_{4}$. The solvent was removed under reduced pressure to obtain a yell ow oil. Y ield: 94\%. IR (film): $\mathrm{v} \mathrm{cm}^{-1} 2120\left(\mathrm{~N}_{3}\right), 1750(\mathrm{C}=\mathrm{O}) .{ }^{1} \mathrm{H} N M R$ $\left(\mathrm{CDCl}_{3}\right): \delta 3.90\left(3 \mathrm{H}, \mathrm{s}, \mathrm{OCH}_{3}\right), 3.81\left(2 \mathrm{H}, \mathrm{s}, \mathrm{CH}_{2}\right) . \mathrm{MS}: \mathrm{m} / \mathrm{z} 115$ $\left(\mathrm{M}^{+}, 17\right), 59$ (base).

General Procedure for the Preparation of Azidocinnamates (23 and 24).42 To a solution of an appropriate aldehyde (20 and 21) (10 mmol) and $\mathbf{2 2}$ (34 mmol) in methanol $(9 \mathrm{~mL})$ a cold solution of sodium methoxide $(30 \mathrm{mmol})$ in methanol $(5 \mathrm{~mL})$ was added. The yellow slurry was stirred at $-15^{\circ} \mathrm{C}$ for $4 \mathrm{~h}$, and then, ice cold water $(36 \mathrm{~mL})$ was added. The precipitate formed was filtered off and washed with water to give yellow crystals.

Methyl 2-Azido-3-phenylacrylate (23). ${ }^{23}$ Y ield: $52 \%$; $\mathrm{mp}$ 39-41 ${ }^{\circ} \mathrm{C}$. IR (Nujol): $\mathrm{v} \mathrm{cm}^{-1} 2120\left(\mathrm{~N}_{3}\right), 1700(\mathrm{C}=\mathrm{O}) .{ }^{1} \mathrm{H}$ NMR $\left(\mathrm{CDCl}_{3}\right): \delta 7.80(2 \mathrm{H}, \mathrm{d}, \mathrm{J} 7.2 \mathrm{~Hz}, \mathrm{Ar}-\mathrm{H}), 7.43-7.28(3 \mathrm{H}, \mathrm{m}, \mathrm{J}$ $7.2 \mathrm{~Hz}, \mathrm{Ar}-\mathrm{H}), 6.91(1 \mathrm{H}, \mathrm{s}, \mathrm{CH}=\mathrm{C}), 3.90\left(3 \mathrm{H}, \mathrm{s}, \mathrm{OCH}_{3}\right) . \mathrm{MS}$ : $\mathrm{m} / \mathrm{z} 203$ (M+, 100), 203 (base).

Mehtyl 2-Azido-3-(1,3-benzodioxol-5-yl)-acrylate (24). Yield: $91 \%$; $\mathrm{mp} 61-62{ }^{\circ} \mathrm{C}$ (from EtOH $/ \mathrm{H}_{2} \mathrm{O}$ ). IR (Nujol): $\mathrm{v} \mathrm{cm}^{-1}$ $2210\left(\mathrm{~N}_{3}\right), 1710(\mathrm{C}=\mathrm{O}) .{ }^{1} \mathrm{H} N \mathrm{NMR}\left(\mathrm{CDCl}_{3}\right): \delta 7.57(1 \mathrm{H}, \mathrm{s}, \mathrm{Ar}-$ $\mathrm{H}), 7.27(1 \mathrm{H}, \mathrm{s}, \mathrm{Ar}-\mathrm{H}), 7.17(\mathrm{HH}, \mathrm{d}, \mathrm{J} 7.8 \mathrm{~Hz}, \mathrm{Ar}-\mathrm{H}), 6.84$ $(1 \mathrm{H}, \mathrm{s}, \mathrm{CH}=\mathrm{C}), 6.82(1 \mathrm{H}, \mathrm{d}, \mathrm{J} 7.8 \mathrm{~Hz}, \mathrm{Ar}-\mathrm{H}) 6.01(2 \mathrm{H}, \mathrm{s}$, $\left.\mathrm{OCH}_{2} \mathrm{O}\right), 3.90\left(3 \mathrm{H}, \mathrm{S}, \mathrm{OCH}_{3}\right) . \mathrm{MS}: \mathrm{m} / \mathrm{z} 247\left(\mathrm{M}^{+}, 100\right), 203$ (base).

General Procedures for the Preparation of Esters (10 and 11). A solution of the azidocinnamates (23 and 24) (4.04 $\mathrm{mmol})$ in xylene $(25 \mathrm{~mL})$ was heated under reflux for $15 \mathrm{~min}$. After the solution was cooled, the pale yellow precipitate formed was filtered and washed with petroleum ether.

Methyl 1H-Indole-2-carboxylate (10). ${ }^{51}$ Yield: $67 \%$; $\mathrm{mp}$ $145-147^{\circ} \mathrm{C}$ (from EtOH/ $/ \mathrm{H}_{2} \mathrm{O}$ ). IR (Nujol): $v \mathrm{~cm}^{-1} 3320(\mathrm{NH})$, $1680(\mathrm{C}=\mathrm{O}) .{ }^{1} \mathrm{H} N \mathrm{NMR}\left(\mathrm{CDCl}_{3}\right): \delta 9.12(1 \mathrm{H}, \mathrm{bs}, \mathrm{NH}), 7.69(\mathrm{lH}$, d, J $8.2 \mathrm{~Hz}, \mathrm{Ar}-\mathrm{H}), 7.41(1 \mathrm{H}, \mathrm{t}, \mathrm{J} 8.0 \mathrm{~Hz}, \mathrm{Ar}-\mathrm{H}), 7.32(1 \mathrm{H}, \mathrm{t}$, J $8.2 \mathrm{~Hz}, \mathrm{Ar}-\mathrm{H}), 7.22(1 \mathrm{H}, \mathrm{s}, \mathrm{Ar}-\mathrm{H}), 7.15(1 \mathrm{H}, \mathrm{t}, \mathrm{J} 8.0 \mathrm{~Hz}$ $\mathrm{Ar}-\mathrm{H}), 3.95\left(3 \mathrm{H}, \mathrm{s}, \mathrm{OCH}_{3}\right)$. MS: $\mathrm{m} / \mathrm{z} 175\left(\mathrm{M}^{+}, 77\right), 143$ (base).

Methyl 5H-[1,3]Dioxolo[4,5-f]indole-6-carboxylate (11). Yield: $79 \% ; \mathrm{mp} 194-195{ }^{\circ} \mathrm{C}$ (from EtOH $-\mathrm{H}_{2} \mathrm{O}$ ). IR (Nujol): v $\mathrm{cm}^{-1} 3319(\mathrm{NH}), 1690(\mathrm{C}=0) .{ }^{1} \mathrm{H} \mathrm{NMR}\left(\mathrm{CDCl}_{3}\right): \delta 11.22(1 \mathrm{H}$, bs, NH), $7.01(1 \mathrm{H}, \mathrm{s}, \mathrm{Ar}-\mathrm{H}), 6.93(1 \mathrm{H}, \mathrm{s}, \mathrm{Ar}-\mathrm{H}), 6.90(1 \mathrm{H}, \mathrm{s}$, $\mathrm{Ar}-\mathrm{H}), 5.93\left(2 \mathrm{H}, \mathrm{s}, \mathrm{OCH}_{2} \mathrm{O}\right), 3.88\left(3 \mathrm{H}, \mathrm{s}, \mathrm{OCH}_{3}\right) . \mathrm{MS}: \mathrm{m} / \mathrm{z} 219$ $\left(\mathrm{M}^{+}, 99\right), 187$ (base). 
Preparation of Methyl 7-Acetyl-5-methyl(ethyl)-5H[1,3]dioxolo[4,5-f]indole-6-carboxylate (26 and 27). A solution of TFAA ( $24 \mathrm{mmol}, 2.8$ equiv for 26; $11 \mathrm{mmol}, 2.8$ equiv for 27), glacial acetic acid (2.8 equiv), and $85 \% \mathrm{H}_{3} \mathrm{PO}_{4}$ (0.32 equiv) in acetonitrile ( $20 \mathrm{~mL}$ for $\mathbf{2 6}$; $10 \mathrm{~mL}$ for 27 ) was stirred at room temperature for $5 \mathrm{~min}$ under a nitrogen atmosphere. Then, a solution of an appropriate indole (13 and 14) $(8.7 \mathrm{mmol}, 1$ equiv) in acetonitrile $(20 \mathrm{~mL}$ for $26 ; 10 \mathrm{~mL}$ for 27) was added, and the mixture was stirred at room temperature for $14 \mathrm{~h}$. The reaction was quenched by addition of ice water, and the violet precipitate formed was filtered, washed with water, and chromatographed over silica gel using petroleum ether and ethyl acetate as the el uent.

Methyl 7-Acetyl-5-methyl-5H-[1,3]dioxolo[4,5-f]indole6-carboxylate (26). Yield: $81 \%$; $\mathrm{mp} 126-128^{\circ} \mathrm{C}$. IR (Nujol): v cm ${ }^{-1} 1640(\mathrm{C}=\mathrm{O}), 1730(\mathrm{C}=\mathrm{O}$ ester $) .{ }^{1} \mathrm{H} \mathrm{NMR}\left(\mathrm{CDCl}_{3}\right): \delta$ $7.40(1 \mathrm{H}, \mathrm{s}, \mathrm{Ar}-\mathrm{H}), 6.79(1 \mathrm{H}, \mathrm{s}, \mathrm{Ar}-\mathrm{H}), 6.01\left(2 \mathrm{H}, \mathrm{s}, \mathrm{OCH}_{2} \mathrm{O}\right)$, $3.97\left(3 \mathrm{H}, \mathrm{s}, \mathrm{OCH}_{3}\right), 3.85\left(3 \mathrm{H}, \mathrm{s}, \mathrm{NCH}_{3}\right), 2.52\left(3 \mathrm{H}, \mathrm{s}, \mathrm{CH}_{3}\right) . \mathrm{MS}:$ $\mathrm{m} / \mathrm{z} 275\left(\mathrm{M}^{+}, 71\right), 260$ (base).

Methyl 7-Acetyl-5-ethyl-5H-[1,3]dioxolo[4,5-f]indole-6carboxylate (27). Yield: $78 \% ; \mathrm{mp} 148-150{ }^{\circ} \mathrm{C}$. IR (Nujol): v $\mathrm{cm}^{-1} 1660(\mathrm{C}=\mathrm{O}), 1700$ ( $\mathrm{C}=\mathrm{O}$ ester). ${ }^{1} \mathrm{H}$ NMR $\left(\mathrm{CDCl}_{3}\right): \delta 7.40$ $(1 \mathrm{H}, \mathrm{s}, \mathrm{Ar}-\mathrm{H}), 6.79(\mathrm{H}, \mathrm{s}, \mathrm{Ar}-\mathrm{H}), 6.00\left(2 \mathrm{H}, \mathrm{s}, \mathrm{OCH}_{2} \mathrm{O}\right), 4.31$ $\left(2 \mathrm{H}, \mathrm{q}, \mathrm{J} 7.2 \mathrm{~Hz}, \mathrm{CH}_{2}\right), 3.97\left(3 \mathrm{H}, \mathrm{s}, \mathrm{CH}_{3}\right), 2.52\left(3 \mathrm{H}, \mathrm{s}, \mathrm{CH}_{3}\right)$, $1.41\left(3 \mathrm{H}, \mathrm{t}, \mathrm{J} 7.2 \mathrm{~Hz}, \mathrm{CH}_{3}\right.$ ). MS: m/z 289 (M+, 71), 274 (base).

Preparation of 7-Acetyl-5-methyl(ethyl)-5H-[1,3]dioxolo[4,5-f]indole-6-carboxylic Acid (28 and 29). A solution of an appropriate ester (26 and $\mathbf{2 7})(1.3 \mathrm{mmol})$ and $\mathrm{KOH}$ pellets (3.6 equiv) in ethanol $(40 \mathrm{~mL}$ ) was stirred under reflux for 3 h. Then, water was added and the solution was acidified with $6 \mathrm{~N} \mathrm{HCl}$. The white precipitate that formed was filtered, washed with water, and collected.

7-Acetyl-5-methyl-5H-[1,3]dioxolo[4,5-f]indole-6-carboxylic Acid (28). Yield: $71 \% ; \mathrm{mp} 258-260^{\circ} \mathrm{C}$. IR (Nujol): v $\mathrm{cm}^{-1} 1710$ ( $\mathrm{C}=\mathrm{O}$ acid). ${ }^{1} \mathrm{H}$ NMR $\left(\mathrm{CDCl}_{3}+\mathrm{DMSO}-\mathrm{d}_{6}\right): \delta 7.38$ $(1 \mathrm{H}, \mathrm{s}, \mathrm{Ar}-\mathrm{H}), 7.08(\mathrm{HH}, \mathrm{s}, \mathrm{Ar}-\mathrm{H}), 6.03\left(2 \mathrm{H}, \mathrm{s}, \mathrm{OCH}_{2} \mathrm{O}\right), 3.88$ $\left(3 \mathrm{H}, \mathrm{s}, \mathrm{NCH}_{3}\right), 3.77-3.45(\mathrm{H}, \mathrm{bs}, \mathrm{COOH}), 2.55\left(3 \mathrm{H}, \mathrm{s}, \mathrm{CH}_{3}\right)$. MS: $\mathrm{m} / \mathrm{z} 261\left(\mathrm{M}^{+}, 5\right), 202$ (base).

7-Acetyl-5-ethyl-5H-[1,3]dioxolo[4,5-f]indole-6-carboxylic Acid (29). Yield: $91 \%$; $\mathrm{mp} 221-223^{\circ} \mathrm{C}$. IR (Nujol): $\mathrm{v} \mathrm{cm}^{-1}$ $1700\left(\mathrm{C}=\mathrm{O}\right.$ acid). ${ }^{1} \mathrm{H} N M R\left(\mathrm{CDCl}_{3}\right): \delta 7.35(1 \mathrm{H}, \mathrm{s}, \mathrm{Ar}-\mathrm{H}), 6.98$ $(1 \mathrm{H}, \mathrm{s}, \mathrm{Ar}-\mathrm{H}), 6.10\left(2 \mathrm{H}, \mathrm{s}, \mathrm{OCH}_{2} \mathrm{O}\right), 4.77(2 \mathrm{H}, \mathrm{q}, \mathrm{J} 7.2 \mathrm{~Hz}$, $\left.\mathrm{NCH}_{2}\right), 4.15-3.65(1 \mathrm{H}, \mathrm{bs}, \mathrm{COOH}), 2.87\left(3 \mathrm{H}, \mathrm{s}, \mathrm{CH}_{3}\right), 1.48(3 \mathrm{H}$, t, J $7.2 \mathrm{~Hz}, \mathrm{CH}_{3}$ ). MS: m/z $275\left(\mathrm{M}^{+}, 7\right), 216$ (base).

Preparation of 1-(5-Methyl(ethyl)-5H-[1,3]dioxolo[4,5f]indole-7-yl)ethanone (8b,d). A mixture of copper chromite ( 0.3 equiv for $\mathbf{8 b}$; 0.37 equiv for $\mathbf{8 d}$ ) and an appropriate acid (28 or $\mathbf{2 9}$ ) $(4.4 \mathrm{mmol}$ for $\mathbf{2 8} ; 1.5 \mathrm{mmol}$ for $\mathbf{2 9}$ ) in quinoline (12 $\mathrm{mL}$ for 28; $5 \mathrm{~mL}$ for 29) was heated in an oil bath at $200{ }^{\circ} \mathrm{C}$ and stirred under a nitrogen atmosphere for $50 \mathrm{~min}$. Then, after the mixture was cooled at $0{ }^{\circ} \mathrm{C}$, water was added and the solution was extracted with ethyl acetate. The organic layer was acidified with $1 \mathrm{~N} \mathrm{HCl}$, washed with water, then with a solution of $\mathrm{NaHCO}_{3}$, again with water, and eventually dried over $\mathrm{MgSO}_{4}$. The solvent was removed in vacuo to give a solid that was triturated with petroleum ether and ethyl acetate and chromatographed over silica gel using hexane and ethyl acetate as eluent.

1-(5-Methyl-5H-[1,3]dioxolo[4,5-f]indole-7-yl)ethanone (8b). Yield: $46 \%$; $\mathrm{mp} 142-145^{\circ} \mathrm{C}$. I R (Nujol): $\mathrm{v} \mathrm{cm}^{-1}$ $1635(\mathrm{C}=\mathrm{O}) .{ }^{1} \mathrm{H} N M R\left(\mathrm{CDCl}_{3}\right): \delta 7.81(1 \mathrm{H}, \mathrm{s}, \mathrm{Ar}-\mathrm{H}), 7.55(1 \mathrm{H}$, $\mathrm{s}, \mathrm{Ar}-\mathrm{H}), 6.76(\mathrm{H}, \mathrm{s}, \mathrm{Ar}-\mathrm{H}), 5.98\left(2 \mathrm{H}, \mathrm{s}, \mathrm{OCH}_{2} \mathrm{O}\right), 3.76(3 \mathrm{H}$, s, $\left.\mathrm{NCH}_{3}\right), 2.46\left(3 \mathrm{H}, \mathrm{s}, \mathrm{CH}_{3}\right)$. MS: $\mathrm{m} / \mathrm{z} 217\left(\mathrm{M}^{+}, 70\right), 202$ (base).

1-(5-Ethyl-5H-[1,3]dioxolo[4,5-f]indole-7-yl)ethanone (8d). Yield: $61 \%$; $\mathrm{mp} 169-171{ }^{\circ} \mathrm{C}$. IR (Nujol): $\mathrm{v} \mathrm{cm}^{-1} 1630(\mathrm{C}=$

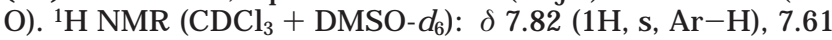
$(1 \mathrm{H}, \mathrm{s}, \mathrm{Ar}-\mathrm{H}), 6.79(\mathrm{H}, \mathrm{s}, \mathrm{Ar}-\mathrm{H}), 5.98\left(2 \mathrm{H}, \mathrm{s}, \mathrm{OCH}_{2} \mathrm{O}\right), 4.12$ $\left(2 \mathrm{H}, \mathrm{q}, \mathrm{J} 7.4 \mathrm{~Hz}, \mathrm{NCH}_{2}\right), 2.47\left(3 \mathrm{H}, \mathrm{s}, \mathrm{CH}_{3}\right), 1.52(3 \mathrm{H}, \mathrm{t}, \mathrm{J} 7.4$ $\mathrm{Hz}, \mathrm{CH}_{3}$ ). MS: $\mathrm{m} / \mathrm{z} 231$ (M+, 71), 260 (base).

X-ray Crystallography. Single crystal X-ray diffraction analysis was carried out at room temperature with a computercontrol led Siemens SMART AXS 100 diffractometer with area detector (CCD) using Mo K $\alpha(\lambda=0.7107 \AA)$. No crystal decay was observed. The reduction and integration of the intensities were carried out with the SAINT program (SAX, area detector integration). ${ }^{52}$ The final reflections, corrected for absorption, were obtained by SADABS. ${ }^{53}$ The phase problem was solved by direct methods, using SIR $97 .{ }^{54}$ F ull-matrix least-squares refinements were carried out with SHELXS 97. ${ }^{55}$ Anisotropic thermal displacement parameters were refined for all non- $\mathrm{H}$ atoms; all $\mathrm{H}$-atoms were distinguished by Fourier maps and refined isotropically. Detailed analyses are listed in Tables 2 and 3 and the Supporting Information.

Biological Materials, Chemicals, and Enzymes. All compounds were dissolved in DMSO, and the stock solutions were stored at $-20{ }^{\circ} \mathrm{C}$. The $\gamma\left[{ }^{32} \mathrm{P}\right]$ ATP was purchased from either Amersham Biosciences or ICN. The expression systems for the wild-type IN and soluble mutant IN ${ }^{\mathrm{F} 185 \mathrm{~K} C 280 \mathrm{~S}}$ were generous gifts of Dr. Robert Craigie, Laboratory of Molecular Biology, NIDDK, NIH, Bethesda, MD.

Preparation of Oligonucleotide Substrates. The oligonucleotides 21top, 5'-GTGTGGAAAATCTCTAGCAGT-3', and 21bot, 5'-ACTGCTAGAGATTTTCCACAC-3', were purchased from Norris Cancer Center Microsequencing Core Facility (University of Southern California) and purified by UV shadowing on polyacrylamide gel. To analyze the extent of 3'processing and strand transfer using $5^{\prime}$-end-labeled substrates, 21top was 5 '-end-labeled using $\mathrm{T}_{4}$ polynucleotide kinase (E picenter, Madison, WI) and $\gamma$ [32P]ATP (Amersham Biosciences or ICN). The kinase was heat-inactivated, and 21 bot was added in 1.5 molar excess. The mixture was heated at 95 ${ }^{\circ} \mathrm{C}$, allowed to cool slowly to room temperature, and run through a spin 25 minicolumn (USA Scientific) to separate annealed double-stranded ol igonucl eotide from unincorporated material.

IN Assays. To determine the extent of 3'-processing and strand transfer, wild-type IN was preincubated at a final concentration of $200 \mathrm{nM}$ with the inhibitor in reaction buffer [50 mM NaCl, 1 mM HEPES, pH 7.5, $50 \mu \mathrm{M}$ EDTA, $50 \mu \mathrm{M}$ dithiothreitol, $10 \%$ glycerol (w/v), $7.5 \mathrm{mM} \mathrm{MnCl} 2,0.1 \mathrm{mg} / \mathrm{mL}$ bovine serum al bumin, $10 \mathrm{mM}$ 2-mercaptoethanol, 10\% DMSO, and $25 \mathrm{mM}$ MOPS, pH 7.2] at $30^{\circ} \mathrm{C}$ for $30 \mathrm{~min}$. Then, $20 \mathrm{nM}$ the $5^{\prime}$-end ${ }^{32} \mathrm{P}$-labeled linear oligonucleotide substrate was added, and incubation was continued for an additional $1 \mathrm{~h}$. Reactions were quenched by the addition of an equal volume (16 $\mu \mathrm{L})$ of loading dye (98\% deionized formamide, $10 \mathrm{mM}$ EDTA, $0.025 \%$ xylene cyanol, and $0.025 \%$ bromophenol blue). An aliquot $(5 \mu \mathrm{L})$ was electrophoresed on a denaturing $20 \%$ polyacrylamide gel (0.09 M tris-borate, pH 8.3, 2 mM EDTA, $20 \%$ acrylamide, and $8 \mathrm{M}$ urea).

The gels were dried, exposed in a Phosphorl mager cassette, analyzed using a Typhoon 8610 Variable Mode Imager (Amersham Biosciences), and quantitated using I mageQuant 5.2. The percent inhibition (\% I) was calculated using the following equation:

$$
\% \mathrm{I}=100 \times[1-(\mathrm{D}-\mathrm{C}) /(\mathrm{N}-\mathrm{C})]
$$

where $C, N$, and $D$ are the fractions of 21-mer substrate converted to 19-mer (3'-processing product) or strand transfer products for DNA alone, DNA plus IN, and IN plus drug, respectively. The I $C_{50}$ values were determined by plotting the logarithm of drug concentration vs percent inhibition to obtain the concentration that produced $50 \%$ inhibition.

Anti-HIV Assays in Cultured Cells. The anti-HIV activity was evaluated in human T-cell line CEM-SS infected with HIV-1 as described by Weislow et al..$^{56}$ In brief, the cells were plated in 96 well plates at $5 \times 10^{3}$ cells/well and infected with $\mathrm{HIV}-1_{\mathrm{RF}}(\mathrm{MOI}=0.3)$. Serial dilutions of compounds were then immediately added to the cells in a final volume of $200 \mu \mathrm{L}$. In each experiment, AZT and dextran sulfate were included as control compounds for anti-HIV activity. The cells were maintained at $37{ }^{\circ} \mathrm{C}$ with $5 \% \mathrm{CO}_{2}$-containing humidified air for 6 days. The cell viability was quantified by absorbance at $450 \mathrm{~nm}$ after $4 \mathrm{~h}$ of incubation with 2,3-bis[2-methoxy-4-nitro5-sul fophenyl ]-5-[(phenylamino)carbonyl ]-2H-tetrazolium hydroxide (XTT) at $0.2 \mathrm{mg} / \mathrm{mL}$. The antiviral activity was graded based on the degree of anti-HIV protection as active (80-100\% protection), moderate (50-79\% protection), and inactive (0- 
$49 \%$ protection). The toxicity of the compounds was determined simultaneously on the same plate in uninfected CEM-SS cells.

Molecular Modeling. The structures of all of the compounds (Table 3 ) were built and minimized using Catalyst (Accelrys, Inc.) running on a multiprocessor Linux PC in parallel with a 24 processor Silicon Graphics Onyx workstation as previously described. ${ }^{30,57}$ All compounds were modeled in their 2,3-enol-tautomeric form based on the solution and the crystal structure of $\mathbf{4 c}$ (Figure 3). Compounds $\mathbf{4 a}-\mathbf{f}$ and $\mathbf{5 a}-\mathbf{e}$ were modeled in their monoanionic carboxylate form. The poling algorithm implemented within Catalyst was used to generate conformations for all of the compounds. ${ }^{58-60}$

F or each compound, all feasible unique conformations were generated over a $20 \mathrm{kcal} / \mathrm{mol}$ range of energies using the best flexible conformation generation method in Catalyst. The subunit B of the core domain X-ray structure of IN (PDB 1BIS) in which all of the active site amino acid residues were resolved was chosen for docking purposes. ${ }^{61} \mathrm{~A} \mathrm{M}^{2+}$ ion was placed in the active site between carboxylate oxygen atoms of amino acid residues D64 and D116 considering the geometry of the $\mathrm{Mg}^{2+}$ ion that was present in the subunit $A$ of IN in PDB IBIS and subunit $A$ in the IN -5 CITEP complex crystal structure (PDB 1QS4). All of the water molecules present in the protein were removed, and hydrogen atoms were added to the protein considering appropriate ionization states for both the acidic and the basic amino acid residues. Docking was performed using version 1.2 of the GOLD: Genetic Optimization for Ligand Docking (Cambridge Crystallographic Data Centre) software package essentially as described. ${ }^{30,62-64}$ In brief, a 20 $\AA$ radius active site was defined considering the carboxylate oxygen atom (OD1) of amino acid residue D64 as the center of the active site. All conformers of the compounds were docked into the active site of the IN. On the basis of the GOLD fitness score, for each molecule, a bound conformation with high fitness score was considered as the best bound conformation. All docking runs were carried out using standard default settings with a population size of 100 , a maximum number of 100000 operations, and a mutation and crossover rate of 95. The fitness function that was implemented in GOLD consisted basically of $\mathrm{H}$-bonding, complex energy, and ligand internal energy terms.

Acknowledgment. This work is dedicated to the memory of Professor Paolo Sanna. We thank Dr. Maria Orecchioni for assistance with NMR spectroscopy, Paola Manconi for MS analysis, Domenico Serra for HPLC analyses, Esmail Rabhar for his help, and Hossein Rezajan and Franco Fiori for their partial financial support to M.S.'s laboratory. We also thank Paula Roberts and Quan-En Yang for their excellent technical assistance with biological assays. We are grateful to Wasyl Tertiuk and Vanna Sanna for their encouragement. The work in M.S.'s laboratory was supported by funds from the Ministero dell'I struzione, del I'U niversità e della Ricerca (MIUR), Rome, Italy. The work in N.N.'s laboratory was supported by funds from the GlaxoSmithK line Drug Discovery Award. The work in Screening Technologies Branch was supported by funds from the $\mathrm{NCl}$, under Contract NO1-CO-12400.

Supporting Information Available: Detailed X-ray crystallographic analyses and a table of elemental analyses. This material is available free of charge via the Internet at http:// pubs.acs.org.

\section{References}

(1) De Clercq, E. New developments in anti-HIV chemotherapy. Biochim. Biophys. Acta 2002, 1587, 258-275.

(2) De Clercq, E. Strategies in the design of antiviral drugs. Nat. Rev. Drug Discovery 2002, 1, 13-25.

(3) Richman, D. D. HIV chemotherapy. Nature 2001, 410, 9951001.
(4) Bushman, F. D.; Craigie, R. Activities of human immunodeficiency virus (HIV) integration protein in vitro: specific cleavage and integration of HIV DNA. Proc. Natl. Acad. Sci. U.S.A. 1991, 88, 1339-1343.

(5) Brown, P. O. Integration; Cold Spring Harbor Press: Cold Spring Harbor, 1999.

(6) Asante-Appiah, E.; Skalka, A. M. HIV-1 integrase: structural organization, conformational changes, and catalysis. Adv. Virus Res. 1999, 52, 351-369.

(7) Engelman, A.; Mizuuchi, K.; Craigie, R. HIV-1 DNA integration: mechanism of viral DNA cleavage and DNA strand transfer. Cell 1991, 67, 1211-1221.

(8) Neamati, N. Structure-based HIV-1 integrase inhibitor design: a future perspective. Exp. Opin. Invest. Drugs 2001, 10, 281296.

(9) Neamati, N. Patented small molecule inhibitors of HIV-1 integrase: a ten-year saga. Exp. Opin. Ther. Pat. 2002, 12, 709724.

(10) Dayam, R.; Neamati, N. Small-molecule HIV-1 integrase inhibitors: The 2001-2002 update. Curr. Pharm. Des. 2003, 9, 17891802.

(11) Pais, G. C. G.; Burke, T. R. Novel aryl diketo-containing inhibitors of HIV-1 integrase. Drugs Future 2002, 27, 11011111.

(12) Goldgur, Y.; Craigie, R.; Cohen, G. H.; Fujiwara, T.; Yoshinaga, T.; Fujishita, T.; Sugimoto, H.; Endo, T.; Murai, H.; Davies, D. R. Structure of the HIV-1 integrase catalytic domain complexed with an inhibitor: A platform for antiviral drug design. Proc Natl. Acad Sci. U S. A. 1999, 96, 13040-13043.

(13) Herr, R. J . 5-Substituted-1H-tetrazoles as carboxylic acid isosteres: medicinal chemistry and synthetic methods. Bioorg. Med. Chem. 2002, 10, 3379-3393.

(14) Espeseth, A. S.; Felock, P.; Wolfe, A.; Witmer, M.; Grobler, J .; Anthony, N.; Egbertson, M.; Melamed, J . Y.; Young, S.; Hamill, T.; Cole, J. L.; Hazuda, D. J. HIV-1 integrase inhibitors that compete with the target DNA substrate define a unique strand transfer conformation for integrase. Proc. Natl. Acad. Sci. U.S.A 2000, 97, 11244-11249.

(15) Hazuda, D. J .; Felock, P.; Witmer, M.; Wolfe, A.; Stillmock, K.; Grobler, J . A.; Espeseth, A.; Gabryelski, L.; Schleif, W.; Blau, C.: Miller, M. D. Inhibitors of strand transfer that prevent integration and inhibit HIV-1 replication in cells. Science 2000, 287, 646-650.

(16) Wai, J . S.; Egbertson, M. S.; Payne, L. S.; Fisher, T. E.; Embrey, M. W.; Tran, L. O.; Melamed, J. Y.; Langford, H. M.; Guare, J. P., J r.; Zhuang, L.; Grey, V. E.; Vacca, J . P.; Holloway, M. K.; Naylor-Olsen, A. M.; Hazuda, D. J .; Felock, P. J .; Wolfe, A. L.; Stillmock, K. A.; Schleif, W. A.; Gabryelski, L. J .; Young, S. D. 4-Aryl-2,4-dioxobutanoic acid inhibitors of HIV-1 integrase and viral replication in cells. J . Med. Chem. 2000, 43, 4923-4926.

(17) Pais, G. C.; Zhang, X.; Marchand, C.; Neamati, N.; Cowansage, K.; Svarovskaia, E. S.; Pathak, V. K.; Tang, Y.; Nicklaus, M.; Pommier, Y.; Burke, T. R., J r. Structure activity of 3-aryl-1,3diketo-containing compounds as HIV-1 integrase inhibitors. J . Med. Chem. 2002, 45, 3184-3194.

(18) Barret, C. B.; Beer, J. R.; Dodd, G. M.; Robertson, A. The chemistry of bacteria. Part VI. The synthesis of a trimethy derivative of the C20 acid from violacein. J . Chem. Soc. 1957, 4810-4813.

(19) Kawai, H.; Kitano, Y.; Mutoh, M.; Hata, G. Synthesis, structure and antitumor activity of a new water-soluble platinum complex, (1R,2R-cyclohexanediamine-N, $\mathrm{N}^{\prime}$ )[2-hydroxy-4-oxo-2-pentenoato(2-)-O2]platinum(II ). Chem. Pharm Bull. (Tokyo) 1993, 41, 357361.

(20) Haeney, H.; Ley, S. V. N-alkylation of indole and pyrroles in dimethyl sulphoxide. J . Chem. Soc., Perkin Trans. 1 1973, 499500.

(21) Bennasar, M.-L.; Vidal, B.; Bosch, J . Biomimetic total synthesis of ervitsine and indole alkaloids of the ervatamine group via 1,4 dihydropyridines. J. Org. Chem. 1997, 62, 3597-3609.

(22) Hemetsberger, H.; Knittel, D.; Weidmann, H. Enazides, Part 3 Thermolysis of a-azidocinnamates; synthesis of indole derivatives. Monatsch. Chem. 1970, 101, 161-165.

(23) Knittel, D. Improved synthesis of a-azidocinnamates and $2 \mathrm{H}$ azirines. Synthesis 1985, 186-188.

(24) Murakami, Y.; Tani, M.; Suzuki, M.; Sudoh, K.; Uesato, M. Tanaka, K.; Yokoyama, Y. Synthetic studies on indoles and reated compounds. XII. A simple general method for the G3 acylation of ethyl indole-2-carboxylate. Chem. Pharm. Bull. 1985, $33,4707-4716$

(25) Kalinowski, H. O.; Berger, S.; Braun, S. Carbon-13 NMR Spectroscopy; J ohn Wiley \& Sons: New York, 1991; p 197.

(26) Pretsch, E.; Seibl, J .; Simon, W. Tables of Spectral Data for Structure Determination of Organic Compounds; SpringerVerlag: Berlin, 1989. 
(27) Bertolasi, V.; Gilli, P.; Ferretti, V.; Gilli, G. Evidence for resonance-assisted hydrogen bonding. 2. Intercorrelation be tween crystal structure and spectroscopic parameters in eight intramolecularly hydrogen bonded 1,3-diaryl-1,3-propanedione enols. J. Am. Chem. Soc. 1991, 113, 4917-4925.

(28) Grobler, J. A.; Stillmock, K.; Hu, B.; Witmer, M.; Felock, P Espeseth, A. S.; Wolfe, A.; Egbertson, M.; Bourgeois, M.; Melamed, J .; Wai, J . S.; Young, S.; Vacca, J .; Hazuda, D. J Diketo acid inhibitor mechanism and HIV-1 integrase: Implications for metal binding in the active site of phosphotransferase enzymes. Proc. Natl. Acad. Sci. U.S.A. 2002, 99, 6661-6666.

(29) Steitz, T. A. A mechanism for all polymerases. Nature 1998, 391, 231-232.

(30) Long, Y. Q.; J iang, X. H.; Dayam, R.; Sanchez, T.; Shoemaker, R.; Sei, S.; Neamati, N. Rational design and synthesis of novel dimeric diketoacid-containing inhibitors of HIV-1 integrase: Implication for binding to two metal ions on the active site of integrase. J. Med. Chem. 2004, 47, 2561-2573.

(31) Sotriffer, C. A.; Ni, H.; McCammon, A. J. HIV-1 Integrase inhibitor interactions at the active site: prediction of binding modes unaffected by crystal packing. J . Am. Chem. Soc. 2000, $122,6136-6137$

(32) Sotriffer, C. A.; Ni, H.; McCammon, J. A. Active site binding modes of HIV-1 integrase inhibitors. J. Med. Chem. 2000, 43, 4109-4117.

(33) Ni, H.; Sotriffer, C. A.; McCammon, J. A. Ordered water and ligand mobility in the HIV-1 integrase-5CITEP complex: a molecular dynamics study. J . Med. Chem. 2001, 44, 3043-3047.

(34) Barreca, M. L.; Lee, K. W.; Chimirri, A.; Briggs, J. M. Molecular dynamics studies of the wild-type and double mutant HIV-1 integrase complexed with the 5CITEP inhibitor: Mechanism for inhibition and drug resistance. Biophys. J . 2003, 84, 1450-1463.

(35) Lins, R. D.; Straatsma, T. P.; Briggs, J. M. Similarities in the HIV-1 and ASV integrase active sites upon metal cofactor binding [in process citation]. Biopolymers 2000, 53, 308-315.

(36) Lins, R. D.; Adesokan, A.; Soares, T. A.; Briggs, J . M. Investigations on human immunodeficiency virus type 1 integrase/DNA binding interactions via molecular dynamics and electrostatics calculations. Pharmacol. Ther. 2000, 85, 123-131.

(37) Lins, R. D.; Briggs, J. M.; Straatsma, T. P.; Carlson, H. A.; Greenwald, J .; Choe, S.; McCammon, J. A. Molecular dynamics studies on the HIV-1 integrase catalytic domain. Biophys. J . 1999, 76, 2999-3011.

(38) Schames, J. R.; Henchman, R. H.; Siegel, J . S.; Sotriffer, C. A.; $\mathrm{Ni}, \mathrm{H}$.; McCammon, J . A. Discovery of a novel binding trench in HIV integrase. J. Med. Chem. 2004, 47, 1879-1881.

(39) Neamati, N.; Marchand, C.; Pommier, Y. HIV-1 integrase inhibitors: Past, present, and future. Adv. Pharmacol. 2000, 49, 147-165.

(40) Neamati, N.; Barchi, J . J ., J r. New paradigms in drug design and discovery. Curr. Top. Med. Chem. 2002, 2, 211-227.

(41) Sechi, M.; Sannia, L.; Orecchioni, M.; Carta, F.; Paglietti, G.; Neamati, N. Structural investigation of 3,5-disubstituted isoxazoles by $\mathrm{H}$-1-nuclear magnetic resonance. J . Heterocycl. Chem. 2003, 40, 1097-1102

(42) Sechi, M.; Angotzi, G.; Dallocchio, R.; Dessì, A.; Carta, F.; Sannia L.; Mariani, A.; Fiori, S.; Sanchez, T.; Movssessian, L.; Plasencia, C.; Neamati, N. Design and synthesis of novel dihydroxyindole2-carboxylic acids as HIV-1 integrase inhibitors. Antiviral Chem. Chemother. 2004, 15, 95-109.

(43) Ottoni, O.; Cruz, R.; Alves, R. Efficient and simple methods of the introduction of the sulphonyl, acyl and alkyl protecting group on the nitrogen of indole and its derivatives. Tetrahedron $\mathbf{1 9 9 8}$ 54, 13915-13928.

(44) Anthony, C. W. Novel synthesis of heterocyclic ketones. J . Org Chem. 1960, 25, 2049-2053.
(45) J ohnson, J . R.; Hasbrouck, R. B.; Dutcher, J . D.; Bruce, W. F. Gliotoxin. The structure of certain indole derivatives relate to gliotoxin. J . Am. Chem. Soc. 1945, 67, 423-430.

(46) Fagan, G. P.; Chapleo, C. B.; Lane, A. C.; Myers, M.; Roach, A. G.; Smith, C. F.: Stillings, M. R.; Welbourn, A. P. Indoline analogues of idazoxan: potent $\alpha 2$-antagonists and $\alpha 1$-agonists. J. Med. Chem. 1988, 31, 944-948.

(47) Daou, B.; Soufiaoui, M. Nouvelle voie de synthese d'arylpyrazolo[4,3-c]quinoleines via la cycloaddition dipolaire-1, -3. Tetrahedron 1989, 45, 3351-3361.

(48) Olgen, S.; Akaho, E.; Nebioglu, D. Synthesis and receptor docking studies of $\mathrm{N}$-substituted indole-2-carboxylic acid esters as a search for COX-2 selective enzyme inhibitors. Eur. J. Med. Chem. 2001, 36, 747-770.

(49) Hlasta, J . D.; Court, J . J . Tandem organometallic addition reactions to $\mathrm{N}$-methoxy-ureas and urethanes in tha preparation of unsymmetrical and symmetrical ketones. Tetrahedron Lett. 1989, 30, 1773-1776.

(50) Ferrer, P.; Avendaño, C.; Söllhuber, M. Synthesis of 5,8dimethoxy-2(1H)-quinolinones by intramolecular Witting reaction. J ustus Liebigs Ann. Chem. 1995, 2, 1895-1899.

(51) Barry, J . F.; Wallace, W. W.; Walshe, N. D. A. On the [4+2] cycloaddition approach to indolo[2,3-a]carbazoles. Tetrahedron 1995, 51, 12797-12806.

(52) SAINT: SAX, A. D. I.; Siemens Analytical Instruments Inc: Madison, WI

(53) SADABS: Siemens Area Detector Absorption Correction Software S. G.; University of Goettingen: Germany, 1996.

(54) Altomare, A.; Burla, M. C.; Camalli, M.; Cascarano, G.; Giacovazzo, C.; Guagliardi, A.; Moliterni, A. G.; Polidori, G.; Spagna R. Sir97: A New Program For Solving And Refining Crystal Structures; Istituto di Ricerca per lo Sviluppo di Metodologie Cristallografiche CNR: Bari, 1997.

(55) Sheldrick, G. M. SHELXL 97: Program for the Refinement of Crystal Structures; University of Göttingen: Germany, 1997.

(56) Weislow, O. W.; Kiser, R.; Fine, D.; Bader, J .; Shoemaker, R. H.; Boyd, M. R. New soluble-formazan assay for HIV-1 cytopathic effects: Application to high-flux screening of synthetic and natural products for AIDS antiviral activity. J . Natl. Cancer Inst. 1989, 81, 577-586.

(57) Catalyst, V.4.7; Accelrys, I.: San Diego.

(58) Smellie, A.; Kahn, S. D.; Teig, S. L. Analysis of conformational coverage. 1. Validation and estimation of coverage. J . Chem. Inf. Comput. Sci. 1995, 35, 285-294.

(59) Smellie, A.; Kahn, S. D.; Teig, S. L. Analysis of conformational coverage. 2. Application of conformational models. J . Chem. Inf. Comput. Sci. 1995, 35, 295-304.

(60) Smellie, A.; Teig, S. L.; Towbin, P. Poling-promoting conformational variation. J . Comput. Chem. 1995, 16, 171-187.

(61) Goldgur, Y.; Dyda, F.; Hickman, A. B.; J enkins, T. M.; Craigie R.; Davies, D. R. Three new structures of the core domain of HIV-1 integrase: An active site that binds magnesium. Proc. Natl. Acad. Sci. U.S.A. 1998, 95, 9150-9154.

(62) GOLD Cambridge Crystallographic Data Centre (CCDC), V1.2; United Kingdom, 2001.

(63) J ones, G.; Willett, P.; Glen, R. C.; Leach, A. R.; Taylor, R. Development and validation of a genetic algorithm for flexible docking. J. Mol. Biol. 1997, 267, 727-748.

(64) Nissink, J . W.; Murray, C.; Hartshorn, M.; Verdonk, M. L.; Cole, J. C.; Taylor, R. A new test set for validating predictions of protein-ligand interaction. Proteins 2002, 49, 457-471. 